\author{
MONIKA MICHALSKA \\ https://orcid.org/0000-0002-4702-4371 \\ Uniwersytet Jagielloński
}

\title{
NIECNI SŁOWIANIE, WYIMAGINOWANY FUNDATOR, BENEDYKTYNI I DZIK. TRADYCJA FUNDACYJNA KLASZTORU CYSTERSÓW W PFORCIE DO KOŃCA XV WIEKU
}

\begin{abstract}
Abstrakt: Obraz najdawniejszych dziejów klasztoru cystersów w Schmölln/Pforcie (1132) był z biegiem lat poddawany wewnątrz wspólnoty klasztornej licznym modyfikacjom i przewartościowaniom. Tradycja fundacyjna ukształtowała się w swojej zasadniczej formie w pierwszej połowie XIII w., a wpływ na nią miał spór prowadzony przez opactwo z biskupstwem naumburskim. Celem artykułu jest prześledzenie zmieniających się poglądów na temat genezy opactwa portyjskiego w źródłach proweniencji klasztornej między XII a XV w.
\end{abstract}

Słowa kluczowe: cystersi, Schmölln/ Pforta, tradycja fundacyjna, XII-XV w.
Abstract: Over the years, the picture of the oldest history of a Cistercian monastery at Schmölln/Pforta (1132) was modified and changed. A foundation tradition in its general form took shape in the first half of the thirteenth century under the impact of a dispute with the bishopric of Naumburg. The purpose of the article is to trace various versions of the Pforta monastery genesis in the source documents issued at the monastery between the twelfth and fifteenth centuries.

Keywords: Cistercian monks, Schmölln/ Pforta, foundation tradition, twelfth-fifteenth centuries.

\section{Wstęp}

Wraz z rozwojem wspólnoty klasztornej wśród jej członków wykształcał się pewien obraz najdawniejszych dziejów zgromadzenia, który pozwalał odpowiedzieć na podstawowe dla istnienia każdej grupy pytania: 
kim jesteśmy? skąd pochodzimy? dokąd zmierzamy? ${ }^{1} \mathrm{Na}$ ów wizerunek składały się wyselekcjonowane oraz poddane wartościowaniu elementy z przeszłości klasztoru, które ulegały nieustannej modyfikacji, adaptując się każdorazowo do aktualnych potrzeb konwentu ${ }^{2}$. Ten proces przekazywania z pokolenia na pokolenie określonej wizji początków wspólnoty klasztornej, określany przez nas jako tradycja fundacyjna, zostanie przedstawiony na przykładzie założonego w 1132 r. opactwa cystersów w Schmölln/Pforcie. Celem artykułu jest zatem analiza treści tradycji, czyli tego, co o swojej przeszłości mówili sami mnisi oraz za pomocą jakich środków, tj. motywów literackich, symboli, nawiązań biblijnych tworzyli oni wizję początków swojej wspólnoty, począwszy od pierwszej połowy XII do końca XV w., co pozwoli ukazać funkcjonujące w średniowieczu warianty opowiadania o genezie opactwa.

Podejmowany przez nas temat klasztornych tradycji fundacyjnych posiada bogatą literaturę przedmiotu. Badania historyków poruszały różnorodne aspekty interesującego nas zagadnienia. Hans Patze analizował proces przenikania się na kartach kronik klasztornych tradycji o powstaniu wielkich rodów możnowładczych z dziejami założonych przez nie wspólnot monastycznych ${ }^{3}$. Z kolei Jörg Kastner badał nośniki tradycji fundacyjnej, tj. rozwój dziejopisarstwa klasztornego poświęconego genezie poszczególnych zgromadzeń mniszych, od form najprostszych do najbardziej złożonych ${ }^{4}$. Relacje między piśmiennictwem klasztornym a tożsamością historyczną, grupową wspólnoty rozpatrywał na kartach swoich prac Hans Werner Goetz ${ }^{5}$. Do modelowych prac poruszających temat tradycji fundacyjnych należy monografia Ludwika Holzfurtnera na temat narracji założycielskich opactw bawarskich za czasów dynastii

${ }^{1}$ E. Berne, The Structure and Dynamics of Organizations and Groups, New York 1973, s. $125-142$.

2 J. Szacki, Tradycja, Warszawa 2011; R. Zimand, Problem tradycji, w: Proces historyczny w literaturze i sztuce. Materiały z sesji naukowej (maj 1956), red. M. Janion, A. Piorunowa, Warszawa 1967, s. 360-379.

${ }^{3}$ H. Patze, Klostergründung und Klosterchronik, „Blätter für deutsche Landesgeschichte" 113, 1977, s. 89-121; idem, Adel und Stifterchronik. Frühformen territorialer Geschichtsschreibung im hochmittelalterlichen Reich, „Blätter für deutsche Landesgeschichte” 100, 1964, s. 8-81; 101, 1965, s. 67-128.

${ }^{4}$ J. Kastner, Historiae fundationum monasteriorum. Frühformen monastischer Institutionsgeschichtsschreibung im Mittelalter, München 1974, Münchener Beiträge zur Mediävistik und Renaissance-Forschung, t. 18.

${ }^{5}$ H.W. Goetz, Zum Geschichtsbewußtsein in der alamannisch-schweizerischen Klosterchronistik des hohen Mittelalters (11.-13. Jahrhundert), „Deutsches Archiv” 44, 1988, s. 455-488; idem, Geschichtsschreibung und Geschichtsbewusstsein im hohen Mittelalter, Berlin 1999, Orbis mediaevalis. Vorstellungswelten des Mittelalters, t. 1. 
Ludolfingów. Badacz ten zanalizował proces powstawania i przekazywania pamięci o początkach wspólnot klasztornych od VIII do XIII w. ${ }^{6}$ Warto przywołać także pracę amerykańskiej badaczki Amy Remensnyder, która przebadała rozwój „pamięci wyobrażeniowej” opactw na terenie południowej Francji, wnosząc ciekawe ustalenia na temat motywów i symboli występujących w klasztornych fundationes ${ }^{7}$. Mity założycielskie klasztorów z terenu Frankonii stały się z kolei przedmiotem badań Christofera Zwanziga ${ }^{8}$. Natomiast Christine Sauer oraz Marcus Späth poświęcili uwagę źródłom ikonograficznym, które przekazywały pamięć o początkach wspólnot klasztornych. Sauer zanalizowała formy, w jakich zakonnicy przedstawiali i utrwalali dla kolejnych pokoleń postać fundatora, Späth zaś w monografii dotyczącej opactwa św. Klemensa w Casaurii przebadał intermedialność nośników treści tradycji fundacyjnej9. Również polscy badacze podejmowali temat klasztornych tradycji fundacyjnych. Warto wymienić chociażby monografię poświęconą tradycji klasztoru benedyktyńskiego w Brauweiler Michała Tomaszka czy publikacje Marcina Pauka dotyczące m.in. opactw w Zdziarze czy Petershausen ${ }^{10}$.

W przypadku Pforty problem tradycji fundacyjnej nie stanowił w dotychczasowych studiach osobnego tematu rozważań. Badacze koncentrowali się przede wszystkim na szczegółowym odtworzeniu procesu fundacyjnego, czego przykładem jest monografia klasztoru pióra Roberta Pahnckego, prace Petry Dorfmüller, Paula Böhmego czy wykład dziejów opactwa w historii Kościoła saskiego w średniowieczu Waltera

${ }^{6}$ L. Holzfurtner, Gründung und Gründungsüberlieferung. Quellenkritische Studien zur Gründungsgeschichte der Bayerischen Klöster der Agilolfingerzeit und ihrer hochmittelalterlichen Überlieferung, Kallmünz 1984, Münchener Historische Studien, Abt. Bayer. Geschichte, t. 11.

7 A. Remensnyder, Remembering Kings Past. Monastic Foundation Legends in Medieval Southern France, New York 1995.

${ }^{8}$ Ch. Zwanzig, Gründungsmythen fränkischer Klöster im Früh- und Hochmittelalter, Sttutgart 2010, Geschichte. Beiträge zur Hagiographie, t. 9.

${ }_{9}$ Ch. Sauer, Fundatio und Memoria. Stifter und Klostergründer im Bild, 1100 bis 1350, Göttingen 1993, Veröffentlichungen des Max-Planck-Instituts für Geschichte, t. 109; M. Späth, Verflechtung von Erinnerung. Bildproduktion und Geschichtsschreibung im Kloster San Clemente a Casauria während des 12. Jahrhunderts, Berlin 2007, Orbis Mediaevalis. Vorstellungswelten des Mittelalters, t. 8.

${ }^{10}$ M. Tomaszek, Klasztor ijego dobroczyńcy. Średniowieczna narracja o opactwie Brauweiler i rodzie królowej Rychezy, Kraków 2007; M. Pauk, Mnisi - fundatorzy - pismo. Cronica Domus Sarensis na tle dziejopisarstwa klasztornego XI-XIV wieku, w: Christianitas Romana. Studia ofiarowane Profesorowi Romanowi Michałowskiemu, red. K. Skwierczyński, Warszawa 2009, s. 234-273; idem, Wspólnota klasztorna jako „środowisko pamięci”. Konwent opactwa Petershausen i podstawy jego tożsamości w pierwszej połowie XII wieku, w: Symboliczne i realne podstawy tożsamości społecznej w średniowieczu, red. S. Gawlas, P. Żmudzki, Warszawa 2017, s. 138-164. 
Schlesingera ${ }^{11}$. Dla interesującego nas tematu szczególną wartość przedstawiają natomiast publikacje dotyczące źródeł traktujących o fundacji klasztoru i ich krytyki. Zalicza się do nich książka Wilhelma Paula Corssena, która zawiera niemal pełny zestaw materiałów potrzebnych do analizy tradycji fundacyjnych Pforty, tj. dyplomy, źródła narracyjne, inskrypcje, a także opisy zabytków materialnych związanych z historią założenia klasztoru ${ }^{12}$. Niezwykle cennych informacji na temat kreowania wizji przeszłości opactwa w pierwszej połowie XIII w. dostarczają z kolei prace Holgera Kundego poświęcone klasztornym falsyfikatom ${ }^{13}$. Należy wspomnieć również o artykule Petry Weigel, dotyczącym wątku słowiańskiego w tradycji klasztoru, a także o tekstach Ernsta Schuberta oraz Helge Jarecki, które zostały poświęcone zabytkom materialnym związanym z fundacją opactwa ${ }^{14}$. Krótki przegląd najważniejszych prac na temat klasztoru w Pforcie wskazuje na brak całościowego opracowania zagadnienia jego tradycji założycielskiej.

${ }^{11}$ R. Pahncke, Schulpforte. Geschichte des Zisterzienserklosters Pforte, Leipzig 1956; P. Dorfmüller, Die Zisterzienser und das Kloster Pforte, Schulpforte 2011; P. Böhme, Zur Geschichte des Cisterzienser-Klosters St. Marien zur Pforte, w: Einladungs-Programm zu der am 23. Mai 1873 stattfindenden dreihundert und dreissigsten Stiftungsfeier der Königlichen Landesschule Pforta, Naumburg 1873, s. 3-38; W. Schlesinger, Kirchengeschichte Sachsens im Mittelalter, s. 2: Das Zeitalter der deutschen Ostsiedlung (1100-1300), Köln-Graz 1962, Mitteldeutsche Forschungen, t. 27, s. 210-217.

12 W. Corssen, Altertümer und Kunstdenkmale des Cisterzienserklosters St. Marien und der Landesschule zur Pforte, Halle 1868.

${ }^{13} \mathrm{H}$. Kunde, Das Zisterzienserkloster Pforte. Die Urkundenfälschungen und die frühe $\mathrm{Ge}$ schichte bis 1236, Köln-Weimar-Wien 2003, Quellen und Forschungen zur Geschichte Sachsen-Anhalts, t. 4. Zob. również: idem, Das Zisterzienserkloster Pforte - eine Fälscherwerkstatt aus dem 13. Jahrhundert Kunde, w: Diplomatische Forschungen in Mitteldeutschland, red. T. Graber, Leipzig 2005, Schriften zur sächsischen Geschichte und Volkskunde, t. 12, s. 145-161; idem, Vaterabt und Tochterkloster. Die Beziehungen zwischen den Zisterzienserklöstern Pforte und Altzelle bis zum ersten Drittel des 13. Jahrhunderts, w: Altzelle. Zisterzienserabtei in Mitteldeutschland und Hauskloster der Wettiner, red. M. Schattkowsky, A. Thieme, Leipzig 2002, Schriften zur sächsischen Landesgeschichte, t. 3, s. 39-67.

${ }^{14} \mathrm{P}$. Weigel, Slawen und Deutsche. Ethnische Wahrnehmungen und Deutungsmuster in der hoch- und spätmittelalterlichen Germania Slavica, w: Ostsiedlung und Landesausbau in Sachsen. Die Kührener Urkunde von 1154 und ihr historisches Umfeld, red. E. Bünz, Leipzig 2008, Schriften zur sächsischen Geschichte und Volkskunde, t. 23, s. 47-94; H. Jarecki, Gründungsgeschichten des Zisterzienserklosters St. Marien zur Pforte (Schulpforte) bei Naumburg, „Deutsche Gesellschaft für Archäologie des Mittelalters und der Neuzeit: Mitteilungen der Deutschen Gesellschaft für Archäologie des Mittelalters und der Neuzeit" 27, 2014, s. 207-214; E. Schubert, Die Arkosolgräber im Sanktuarium der Zisterzienser-Klosterkirche in Schulpforta, w: idem, Dies diem docet. Ausgewählte Aufsätze zur mittelalterlichen Kunst und Geschichte in Mitteldeutschland. Festgabe zum 75. Geburtstag, Köln 2003, Quellen und Forschungen zur Geschichte Sachsen-Anhalts , t. 3, s. 443-448. 
Dla klasztoru portyjskiego dysponujemy niezwykle bogatym materiałem źródłowym, który ukazuje proces tworzenia się tradycji o najdawniejszych dziejach opactwa, od samych początków klasztoru aż do XV w. Pierwsze uchwytne źródłowo wzmianki o Schmölln/Pforcie pochodzą z dyplomów wystawionych w XII w., tym samym ukazując najświeższą, jeszcze wolną od działań procesów mitotwórczych pamięć dotyczącą fundacji klasztoru, która była podstawą dla wszystkich późniejszych wariacji na temat genezy opactwa ${ }^{15}$. Próby spisania najdawniejszych dziejów Pforty mnisi podjęli się dopiero w pierwszej połowie XIII w., co jest charakterystyczne dla dziejopisarstwa klasztornego. Odstęp czasowy między fundacją wspólnoty a spisaniem jej dziejów wynosił w przypadku starych frankijsko-ottońskich opactw kilka stuleci, dla młodszych zgromadzeń zaś od jednego do trzech pokoleń. Potrzeba utrwalenia tradycji o początkach pojawiała się zazwyczaj w momencie, jak wykazał to w swoich badaniach nad klasztorami szwabskimi Goetz, gdy brakowało już bezpośrednich świadków opisywanych wydarzeń, tj. mnichów należących do konwentu założycielskiego, którzy pełnili funkcję strażników pamięci ${ }^{16}$.

Impulsem stał się spór toczony z biskupem Naumburga Engelhardem o ziemie nadane opactwu przez jego poprzednika, biskupa Bertolda II (przede wszystkim o wieś Flemmingen), które ten ostatni miał przekazać zakonnikom portyjskim bez zgody swojej kapituły. W związku ze sporem w klasztorze doszło do sporządzenia kilku falsyfikatów, których celem było umocnienie praw opactwa do posiadanego majątku ${ }^{17}$. Między 1209 a 1213 r. zostało spisanych trzynaście falsyfikatów, z czego aż w ośmiu został poruszony temat fundacji i translokacji klasztoru ${ }^{18}$. Są to dwa dokumenty biskupa Naumburga Udona I z 1140 i 1145, dyplom króla Konrada III z 1140, następnie dokument Udona II z 1168, cesarza Fryderyka I z 1180, dwa dyplomy biskupa Naumburga Bertolda II z 1205 oraz jeden biskupa Engelharda I z 1207 r. ${ }^{19}$ Wykreowana w falsyfikatach klasztornych wizja przeszłości opactwa znalazła swoje rozwinięcie w spisanej w drugiej połowie XIII w. nocie o fundacji klasztoru zatytułowanej Exordium monasterii Portensis ${ }^{20}$. Dziełko to znajduje się w klasztornym kartularzu, którego autorem był prawdopodobnie opat Pforty, Teodoryk II $^{21}$.

15 Urkundenbuch des Klosters Pforte, t. 1: 1132-1300 (dalej: UP 1), wyd. P. Böhme, Halle 1893, nr 2, 5, 7, 10, 19, 35.

${ }^{16}$ H.W. Goetz, Zum Geschichtsbewußtsein, s. 466-467.

17 H. Kunde, Das Zisterzienserkloster Pforte, s. 109-123.

18 Ibidem, s. 102.

19 UP 1, nr 3, 4, 8, 16, 24, 60 (dyplom w dwóch kopiach), 62.

20 Ibidem, s. 7-9.

${ }^{21}$ Ibidem, s. 7; W. Corssen, op. cit., s. 74-75. 
W XV w. obok źródeł pisanych pojawiły się także nowe nośniki tradycji fundacyjnej, które łączyły obraz z tekstem i skierowane były nie tylko do wspólnoty klasztornej, ale także do szerszej publiczności. Chodzi przede wszystkim o inskrypcję informującą o założeniu klasztoru wraz z obrazowym przedstawieniem historii fundacyjnej ze ściany południowej klasztoru w Pforcie, a także o figury grafa Brunona i biskupa Udona z kościoła klasztornego ${ }^{22}$. Treść inskrypcji, a także towarzyszące jej przedstawienie wizualne nie dotrwały do dnia dzisiejszego ${ }^{23}$. Informacje o nich przekazują jednak dobrze zorientowane w historii Pforty źródła nowożytne ${ }^{24}$.

\section{Fundator}

W dyplomach współczesnych powstawaniu klasztoru portyjskiego brak bezpośrednich informacji na temat fundatora opactwa. Jednak da się zauważyć, iż postacią, która pojawiała się w nich najczęściej, był biskup naumburski Udo I. Wedle dyplomów to biskup dokonał translokacji klasztoru, czynił na jego rzecz nadania, a także służył zakonnikom swoją radą i pomocą ${ }^{25}$. Dopiero w dokumencie biskupa Naumburga Bertolda II, który powstał między 1186 a 1190 r., a więc w ok. 40 lat po śmierci Udona I, klasztor zostaje określony wprost jako fundacja biskupia ${ }^{26}$. Jeśli weźmie się pod uwagę zaangażowanie Udona I w proces zakładania klasztoru i pojawianie się jego imienia w najstarszych dyplomach dotyczących klasztoru, to dojdziemy do przekonania, że właśnie on był w myśl dyplomu założycielem Schmölln/Pforty.

Tradycja ta znalazła swoją kontynuację w dwóch falsyfikatach spisanych w Pforcie na początku XIII w. Są nimi dyplomy biskupa Udona I z 1145 r. oraz Udona II z 1168 r. Pierwszy z nich w charakterystyczny

${ }^{22}$ W. Corssen, op. cit., s. 271-273.

${ }^{23}$ W pracy opieramy się na edycji treści inskrypcji zawartej w pracy Corssena, ibidem, s. 76-77 (Bruchstück eines lateinischen Gedichtes in Leonischen Versen, dalej: Wiersz portyjski).

${ }^{24}$ Jako pierwszy informację o nich podał mnich z klasztoru w Bosau Paul Lange w swojej pracy Chronica Numburgensis opublikowanej w 1536 r.: „Anno Dom. MCXXXI facta est fundatio per Brunonem et Willam uxorem, sicut in pariete monasterii adhuc seriptum et pictum est" (P. Lange, Chronica Numburgensia, w: Scriptores rerum Germanicarum, praecipue Saxonicarum, t. 2, wyd. J.B. Mencke, Leipzig 1728, s. 21). Autor kroniki naumburskiej nie odnotował jednak ani tekstu inskrypcji, ani nie opisał szczegółowo obrazu. Uczynił to dopiero w 1612 r. rektor szkoły Schulpforte Justin Bertuch w swoim dziele Chronicon Portense, która to praca dotyczyła historii klasztoru i założonej na jego miejscu w 1543 r. szkoły (J. Bertuch, Chronicon Portense, Leipzig 1612, s. 17-18).

${ }^{25}$ UP 1, nr 2, 5, 7, 10, 19.

26 „Portensem ecclesiam a predecessoribus nostris institutam”, ibidem, nr 35, s. 53. 
dla klasztornych opowieści o fundacji klasztoru sposób odtwarza przebieg fundacji opactwa. Poczynając od pojawienia się w duszy biskupa intencji założenia klasztoru, której autorem był sam Stwórca, następnie poprzez fazę namysłu nad sposobem, w jaki ów cel można osiągnąć, dalej poprzez realizację zamysłu, tj. wystaranie się o mnichów z opactwa macierzystego z Walkenried oraz sprowadzenie ich do Schmölln, a kończąc na translokacji wspólnoty do Pforty i wyznaczenie jej odpowiedniego uposażenia ${ }^{27}$. Jednak również i w tym świadectwie nie pada w stosunku do Udona I określenie fundator. Dopiero w dokumencie biskupa Udona II myśl ta zostaje wyrażona jednoznacznie. Po pierwsze, podobnie jak miało to miejsce w dyplomie Bertolda II, klasztor zostaje określony jako fundacja biskupia ${ }^{28}$. Po drugie, pada w nim imię fundatora: ,tegoż miejsca fundator świętej pamięci biskup Udo"29.

Inną tradycję dotyczącą osoby założyciela klasztoru przywołuje z kolei falsyfikat z 1140 r. ${ }^{30}$ Intencja założenia klasztoru, wybór cystersów, a także uposażenie konwentu, które dyplom z 1145 łączył z biskupem Udonem I, zostały przypisane zupełnie nowej postaci, a mianowicie grafowi Brunonowi z Pleissengau. Wedle falsyfikatu graf Bruno za zgodą i wolą swojej rodziny ufundował i uposażył nieznaną bliżej wspólnotę klasztorną, przeznaczając na ten cel jedną trzecią swoich rodowych dóbr. Fundacja ta nie prosperowała jednak należycie. Dlatego też graf postanowił oddalić ze Schmölln dotychczasowych zakonników, a na ich miejsce sprowadzić cystersów. Jako że Bruno nie był już w stanie samodzielnie zrealizować swojego planu, przywołał do siebie biskupa Udona I i przez wzgląd na łączące ich pokrewieństwo powierzył mu misję założenia klasztoru ${ }^{31}$. Kolejne elementy opowiadania powtarzają dość wiernie przebieg wydarzeń przedstawiony we wcześniej analizowanych dyplomach na czele z dokumentem z 1145 r., tj.: starania biskupa o uzyskanie konwentu z Walkenried, osadzenie cystersów w Schmölln, następnie translokacja klasztoru do Pforty, a wreszcie zobowiązanie Udona I udzielenia mnichom stosowanego wyrównania za niekorzystną dla nich zamianę ziemi. Chociaż w dyplomie nie pada ani razu słowo fundator, to w kontekście prawa kanonicznego, które za zasadniczy warunek przypisania danej osobie tytułu fundatora klasztoru uznawało przekazanie przez nią jeszcze przed aktem konsekracji kościoła fundusu, a więc odpowiedniego majątku ziemskiego potrzebnego do wzniesienia instytucji kościelnej, był

27 Ibidem, nr 8.

${ }^{28}$ Ibidem, nr 16.

29 „eiusdem loci fundator, pie memorie Uto episcopus”, ibidem.

30 Ibidem, nr 3.

31 Ibidem. 
nim graf Bruno z Pleissengau ${ }^{32}$. Świadczy o tym również sposób, w jaki Bruno został sportretowany w dyplomie z 1140 r. ${ }^{33}$ Jego charakterystyka zawiera najważniejsze dla postaci fundatora elementy: został określony jako przesławny mąż, a także jako krewniak biskupa Naumburga Udona I, co wskazywało na jego wysoką pozycję społeczną oraz szlachetne urodze$n^{3} e^{34}$. Graf miał odznaczać się także szczególną pobożnością, która przejawiała się w fundowaniu instytucji kościelnych, a także hojnym ich uposażaniu. Temu ostatniemu wątkowi dyktator dyplomu poświęcił zresztą najwięcej uwagi, ukazując Brunona jako człowieka bogatego, cieszącego się ziemską pomyślnością. Przedefiniowaniu uległa także rola biskupa Udona I w procesie fundacji klasztoru. Chociaż nie został całkowicie wyeliminowany z tradycji klasztornej, to z założyciela opactwa stał się on jedynie krewnym fundatora oraz realizatorem woli zmarłego grafa ${ }^{35}$. Wątpliwości co do rzeczywistego istnienia grafa Brunona z Pleissengau wysunął ostatnio Kunde. Wedle tego badacza był on postacią całkowicie fikcyjną, wykreowaną na potrzeby wspólnoty klasztornej w pierwszej połowie XIII w., prawdziwym fundatorem klasztoru zaś był biskup Udo ${ }^{36}$. Historyk ten zwrócił uwagę na brak jakichkolwiek informacji na temat grafa we współczesnych mu źródłach spisanych poza opactwem portyjskim, które mogłyby potwierdzić klasztorną wizję dziejów ${ }^{37}$.

32 Ch. Sauer, op. cit., s. 28.

${ }^{33}$ Zob. R. Michałowski, Święta moc fundatora klasztoru (Niemcy XI-XII wieku), KH 91, 1984, 1, s. 3-24; idem, Princeps fundator. Studium z dziejów kultury politycznej w Polsce X-XIII wieku, Warszawa 1989.

${ }^{34}$ UP 1 , nr 3.

35 Hierarchia ważności osób partycypujących w fundacji klasztoru ulegała modyfikacjom na przestrzeni dziejów. Ciekawym przykładem dla tego procesu jest tradycja klasztoru w Maulbronn. Opactwo zostało założone w 1138 r. przez rycerza Waltera von Lomesheim w miejscowości Eckenweiher. Około roku 1146 klasztor z powodu niedogodności terenu został translokowany przez biskupa Gunthera do znajdującego się na ziemi biskupstwa spirskiego Maulbronn (U. Knapp, Das Kloster Maulbronn. Geschichte und Baugeschichte, Stuttgart 1997, s. 21-30). W czasie toczonego w drugiej połowie XIII w. sporu o prawa do wójtostwa nad klasztorem między rodem Enzenbergów a biskupstwem Spiry zakonnicy popierający pretensje biskupów sporządzili falsyfikat dyplomu biskupa Gunthera, wedle którego opactwo zostało przeniesione przez biskupa i na nowo osadzone na majątku własnym katedry spirskiej „in fundum nostre ęcclesie, scilicet Mulenbrunnen" (Wirtembergisches Urkundenbuch, t. 2: 1138-1212, oprac. E. Kausler, Stuttgart 1858 [dalej: WUB], nr 327). W dyplomie biskupa Henryka II z 1270, który opierał się na owym falsyfikacie, biskup Gunther nazwany jest już wprost fundatorem klasztoru (WUB 7, nr 2155). W samej tradycji klasztoru za założycieli uchodzili zarówno Walter von Lomesheim, jak i biskup Gunther (Ch. Sauer, op. cit., s. 128-130).

${ }^{36}$ H. Kunde, Vaterabt und Tochterkloster, s. 52.

37 H. Kunde, Das Zisterzienserkloster Pforte, s. 19-20. 
Ponadto ziemia, na której został ufundowany klasztor, była najprawdopodobniej w posiadaniu biskupów Naumburga ${ }^{38}$. Fundacja opactwa wpisywała się zresztą w program fundacyjny biskupów naumburskich, który miał na celu intensyfikację prowadzonej przez nich akcji chrystianizacyjnej ludności słowiańskiej.

Należałoby zatem zadać pytanie o powód, dla którego zakonnicy portyjscy wprowadzili postać grafa Brunona do klasztornych dziejów. Tak silne zmiany w tradycji fundacyjnej danego zgromadzenia następowały najczęściej w sytuacji kryzysu wspólnoty spowodowanego jej problemami tak wewnętrznymi, jak i zewnętrznymi. Momentem kryzysowym był często konflikt $\mathrm{z}$ miejscowym biskupem. Tak też było w przypadku Pforty. Celem zakonników było wykazanie niezależności opactwa od biskupów Naumburga. Wedle dokumentu klasztor został ufundowany na wolnej ziemi, przez wolnego wielmożę, biskup zaś, dokonując przenosin konwentu do Pforty, zobowiązał się do przestrzegania wolności, którymi opactwo cieszyło się w Schmölln. Ponadto podkreślane przez dyplom pokrewieństwo między grafem Brunonem a biskupem Udonem I pozwalało wykazać, iż klasztor nie był w żaden sposób związany z biskupstwem naumburskim jako instytucją, gdyż protekcja Udona I nad fundacją wynikała jedynie $\mathrm{z}$ faktu, iż był on krewnym fundatora klasztoru.

Tradycja o grafie Brunonie z Pleissengau jako fundatorze klasztoru znalazła swoje miejsce także w Exordium monasterii Portensis. Autor dziełka poszerzył skąpe wiadomości na temat Brunona, a także rozbudował te znajdujące się w dyplomie z 1140 r. Dość ogólnikowe wyrażenie „przesławny mąż graf Bruno", za pomocą którego dyktator dyplomu z 1140 r. wprowadził do opowiadania postać grafa, zostało zastąpione informacją o pochodzeniu Brunona z przesławnego rodu ${ }^{39}$. Temat rodziny grafa, który w dokumencie biskupa Udona I pojawił się jedynie przy odnotowaniu, iż Bruno dokonał fundacji klasztoru za zgodą swoich dziedziców,

${ }^{38}$ Ziemia, na której został ufundowany klasztor, była najprawdopodobniej w posiadaniu biskupów Naumburga. W 976 r. biskupstwo otrzymało liczne nadania z rąk Ottona II, w tym dziewięć wsi leżących w Pleissengau: Drescha, Gödissa, Leesen, Monstab, Zehma, Pauritz, Röda, Cebecur, Buosendorf (ibidem, s. 137; A. Thieme, Die Burggrafschaft Altenburg. Studien zu Amt und Herrschaft im Übergang vom hohen zum späten Mittelalter, Lipsk 2001, Schriften zur Sächsischen Landesgeschichte, t. 2, s. 131). Z kolei w 1066 r. Henryk IV przekazał biskupowi Naumburga szerzej nieokreślone opactwo w Schmölln wraz z ziemiami, które jako uposażenie przekazała na ten cel jego matka Agnieszka (H. Kunde, Das Zisterzienserkloster Pforte, s. 138). Późniejsze źródła, wyłączając tradycję klasztoru w Pforcie, milczą o funkcjonowaniu wspólnoty klasztornej w tym miejscu, co wskazywałoby na jej upadek i przejęcie ziemi przez biskupa i jego kapitułę (ibidem).

39 "comes quidam Bruno nomine, de illustri prosapia originem trahens", UP 1, nr 3, s. 7. 
a także przy okazji podkreślenia pokrewieństwa między biskupem a grafem, w Exordium został znacząco rozwinięty. Mianowicie twórca fundatio w miejsce bezimiennych dziedziców, za których aprobatą i wolą Bruno miał założyć w Schmölln klasztor, umieścił postać żony grafa, Willi, scharakteryzowanej jako pobożna, religijna i wierna małżonka, która poparła plany swojego męża. Wątek dziedziców grafa został zresztą jednoznacznie wyjaśniony w Exordium, w którym wprost zostało stwierdzone, iż Bruno i Willa nie mieli żadnego potomstwa. Autor noty podkreślał także pokrewieństwo między Brunonem i Udonem (consanguineus, propinquitas $)^{40}$.

Podobnie jak w dyplomie z 1140 r., graf Bruno został sportretowany jako człowiek pobożny, fundator aż trzech wspólnot klasztornych: konwentu żeńskiego, benedyktynów oraz cystersów. Dwie nieudane fundacje w Schmölln przypominają nieco historię klasztoru cysterskiego Zdziar nad Sazawą. W Cronica Domus Sarensis anonimowy autor opisał fundację cysterską Jana z Polnej w Nižkovie, która poprzedzała założenie klasztoru w Zdziarze ${ }^{41}$. Opat klasztoru macierzystego - Sławek z Osseku - zadecydował o powrocie mnichów do macierzy z powodu biedy i konfliktów wewnętrznych. Kronikarz nie ma wątpliwości, że powodem nieudanej fundacji był brak Bożej łaski. Jednak nie łączył tego faktu z jakimiś grzechami czy też błędami samego Jana, który miał być człowiekiem pobożnym i roztropnym, zasługującym na życie wieczne ${ }^{42}$. Podobnie autor Exordium nie obwinia w żaden sposób za nieudane fundacje Brunona. Wydaje się zresztą, iż ukazanie upadku wspólnot poprzedzających szarych mnichów miało na celu przede wszystkim podkreślenie wyjątkowości samego zakonu cysterskiego.

Rozwinięty został także wątek bogactwa grafa Brunona. Nie tylko miał on posiadać znaczny majątek, o czym już wspominał dyplom z 1140 r., ale także wiele posiadłości ziemskich. Przedcysterskim fundacjom w Schmölln podarował jedną trzecią Pleissengau, umierając zaś przekazał na ręce Udona nie tylko Schmölln, ale także kilka wsi, których powierzchnia miała wynosić 1100 łanów $^{43}$.

Tradycję wiążącą powstanie klasztoru z postacią Brunona powtórzyła także piętnastowieczna inskrypcja. Pojawiły się w niej również nowe informacje na temat grafa. Należy do nich wzmianka o jego dzieciach:

40 Ibidem, s. 7-8.

${ }^{41}$ Cronica Domus Sarensis, w: Fontes rerum Bohemicarum, t. 2, wyd. J. Emler, Praha 1874, s. 523-524.

${ }^{42}$ Ibidem, s. 524; M. Pauk, Mnisi - fundatorzy - pismo, s. 258-259, 264.

${ }^{43}$ UP 1, s. 7-8. 
synu Oetwinie i córce Garburgis ${ }^{44}$. Temu pierwszemu poświęcone zostało także malowidło towarzyszące inskrypcji, które ukazywało jego śmierć w czasie polowania na dzika ${ }^{45}$. Wydaje się, że inspiracją dla autora inskrypcji mogła być zapiska w dokumencie biskupa Udona z 1140 r., w którym była mowa o dziedzicach grafa ${ }^{46}$. Wprowadzenie postaci dzieci Brunona do opowiadania o początkach klasztoru miało, po pierwsze, poszerzyć dość skąpe wiadomości o fundatorze, a po drugie, za pomocą historii Oetwina i Garburgis wyjaśnić przedcysterskie losy Schmölln. Śmierć syna stała się impulsem do założenia przez Brunona konwentu mniszek, których opatką została z kolei jego córka Garburgis ${ }^{47}$.

$\mathrm{W}$ połowie XV w. wykonano rzeźby przedstawiające grafa Brunona, biskupa Udona oraz patronów klasztoru - Najświętszą Marię Pannę oraz Jana Chrzciciela, które umieszczono w dwóch niszach ściennych znajdujących się $\mathrm{w}$ prezbiterium ${ }^{48}$. W północnej usytuowane zostały figury Brunona (fundatora) oraz NMP (głównej patronki) ${ }^{49}$. Graf przedstawiony został w zbroi, w lewej ręce trzymał miecz wraz z tarczą, na której znajdował się herb ziemi plisenskiej (Pleißenland), w prawej zaś model kościoła klasztornego ${ }^{50}$. W południowej niszy usytuowano natomiast podobizny biskupa Udona wraz z Janem Chrzcicielem, drugim patronem klasztoru ${ }^{51}$. Udo I ukazany został $\mathrm{w}$ stroju pontyfikalnym, w jednej jego ręce znajdował się pastorał, a w drugiej herb biskupstwa naumburskiego ${ }^{52}$. Justin Bertuch przekazał w swojej kronice dziś już niewidoczne inskrypcje towarzyszące rzeźbie Brunona: „Graf Bruno fundator tegoż klasztoru” oraz Udona: „Udo biskup Naumburga, krewny fundatora” ${ }^{3}$. Program ikonograficzny jest dość czytelny. Zgrupowanie po jednej stronie wizerunków NMP oraz grafa Brunona podkreślało ich pierwszoplanową rolę w dziejach klasztoru. Ponadto Bruno został nie tylko przedstawiony $\mathrm{z}$ atrybutem typowym dla fundatora klasztoru, jakim był model opactwa, ale także nazwany w inskrypcji założycielem wspólnoty. Z kolei druga grupa figur ukazywała postacie również ważne dla historii Pforty,

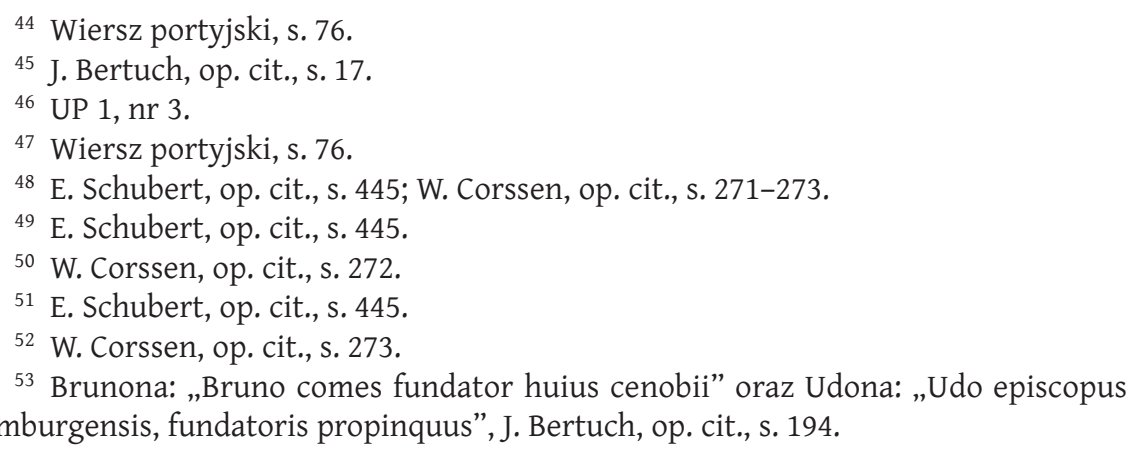


ale pełniące rolę pomocniczą. Akcentował to napis pod rzeźbą Udona, w którym został on nazwany krewniakiem fundatora, co nawiązywało do tradycji fundacyjnej klasztoru zawartej w dokumentach i Exordium monasterii Portensis. Wizerunek grafa Brunona trzymającego model kościoła znajduje się także na zachodniej fasadzie przedbramia klasztornego, które zostało wybudowane w XIX w. na miejscu starego ${ }^{54}$.

\section{Dzieje przedcysterskie}

Przywoływanie przedcysterskich dziejów wspólnot szarych mnichów, a zwłaszcza benedyktyńskich, stanowiło częsty motyw w cysterskich tradycjach fundacyjnych. Wątek ten wiązał się ściśle z początkami macierzy wszystkich klasztorów cysterskich, a mianowicie opactwa w Cîteaux. Trzonem opowieści o fundacji Cîteaux był konflikt między benedyktynami z Molesmes a mnichami reformatorami na czele z opatem Robertem, którzy opuścili benedyktyński klasztor powodowani gorliwością w restrykcyjnym przestrzeganiu Reguły św. Benedykta. Stąd też opis benedyktyńskich początków danej wspólnoty służył często nie tylko do podkreślania dawności zgromadzenia czy praw majątkowych szarych mnichów do dóbr przejętych po benedyktynach, ale także jako sposób wykazania wyższości zakonu cysterskiego nad czarnymi mnichami, których przedstawiano często jako niedbałych w sprawach służby Bożej, a także jako niepotrafiących, w przeciwieństwie do szarych mnichów, sprostać trudnym warunkom życia ${ }^{55}$.

W przypadku klasztoru portyjskiego motyw ten pojawił się po raz pierwszy w dyplomie biskupa Udona I z 1140 r. W narracji dokumentu pierwsza wspólnota mnisza, która została ufundowana przez grafa Brunona w Schmölln, nie została jednak bliżej scharakteryzowana, określono ją po prostu jako „cenobium” oraz zgromadzenie pobożnych osób ${ }^{56}$. Dyktator dyplomu nie tylko przywołał miejsce, w którym został założony klasztor, jego bogate uposażenie, ale także powód, dla którego Bruno postanowił usunąć dawną wspólnotę, a w jej miejsce sprowadzić cystersów. Mianowicie klasztor wraz z upływem czasu coraz bardziej

54 Torhaus, zachodnia fasada: https://www.mdm-online.de/LGSuche_load.do?pk= \%2523BGBhZ8ZHwWY\%253D (dostęp: 8 XII 2017).

${ }^{55} \mathrm{~J}$. France, Cistercian Foundation Narratives in Scandinavia in Their Wider Context, „Cîteaux” 43, 1992, s. 144-148.

56 „comes Bruno consanguineus noster, cum voluntate et consensu heredum suorum in loco, qui dicitur Zmolne, cenobium fundans et religiosas inibi personas collocans de hereditate sua", UP 1, nr 3, s. 4. 
podupadał, mnisi zboczyli z drogi klasztornej dyscypliny, a z ich działalności nie było żadnego pożytku. Ta negatywna opinia o poprzedzającej szarych mnichów wspólnocie została jeszcze dodatkowo spotęgowana poprzez przywołanie $\mathrm{w}$ tym samym passusie pochwały zakonu cysterskiego ${ }^{57}$. Wizerunki obu wspólnot zbudowane są na zasadzie kontrastu: pierwsza chyli się ku upadkowi moralnemu, jej członkowie nazwani są osobami zupełnie nieużytecznymi, druga zaś słynie z pobożnego sposobu życia i posiada dobrą opinię w całym świecie chrześcijańskim.

Wątek przedcysterskich dziejów Schmölln rozwinął w znaczący sposób autor Exordium. Przede wszystkim wprowadził on do swojego opowiadania nie jedno zgromadzenie, jak to podawał dokument biskupa Udona I, a dwa. Pierwszym była wspólnota mniszek, a drugim konwent benedyktynów. Co ciekawe, cały passus im poświęcony został niemal w całości przejęty z dyplomu z $1140 \mathrm{r}{ }^{58}$ Twórca Exordium dokonał w nim jednak istotnych zmian. Mianowicie w dokumencie biskupa Udona tematowi pierwotnego zgromadzenia zostały poświęcone dwa fragmenty tekstu. W pierwszym dyktator dyplomu omówił sprowadzenie do Schmölln bliżej nieokreślonej wspólnoty zakonnej, a także jego bogate uposażenie ${ }^{59}$. W drugim z kolei opisał upadek zgromadzenia w miarę upływu czasu, podał przyczyny tego stanu rzeczy: nieużyteczność mnichów oraz nieprzestrzeganie reguły, a także ukazał zastąpienie go przez cystersów ${ }^{60}$. Z kolei autor Exordium pierwszą, a także początek drugiej części, w której pojawiała się informacja o upadku wspólnoty, połączył z historią konwentu żeńskiego ${ }^{61}$. Corssen próbował tłumaczyć pojawienie się konwentu żeńskiego w historii Schmölln błędnym odczytaniem przez autora Exordium wyrażenia religiosas personas, co jego zdaniem - jako że

${ }^{57}$ Ibidem.

58 Dyplom z 1140 r: „cum voluntate et consensu heredum suorum in loco, qui dicitur Zmuolne, cenobium fundans et religiosas inibi personas collocans de hereditate sua, quam amplam valde possidebat, adeo locum illum ditavit et dotavit, ut terciam ferme partem pagi, qui Plisne nuncupatur, eidem cenobio donatione legitima sollempniter delegaret. Verum cum processu temporis religio inibi claudicaret, et ipse iam in extremis ageret”, UP 1, nr 3; Exordium monasterii Portensis: „cum consensu pie uxoris sue, que Willa vocabatur, aliorumque heredum suorum cenobium quoddam in loco, qui dicitur Zmolne, pro anime sue remedio fundans de hereditate sua, quam inibi possidebat, in tantum illud ditavit et dotavit, ut terciam ferme partem pagi, qui Plisne nuncupatur, eidem cenobio libera donatione conferret, congregationem sanctimonialium ad serviendum deo in eo collocans. Sed procedente tempore cum rebus minus prospere succedentibus iam ad defectum conventus ille tendere inciperet", ibidem, s. 7.

${ }^{59}$ Ibidem, nr 3.

60 Ibidem.

${ }^{61}$ Ibidem, s. 7. 
oba wyrazy mają rodzaj żeński - mogło skutkować powstaniem domysłu o jakichś mniszkach, które zostały sprowadzone przez grafa Brunona ${ }^{62}$. Propozycja ta wydaje się jednak mało możliwa, gdyż dla uczonego bądź co bądź zakonnika, autora Exordium, musiało być raczej wiadome, że rzeczownik persona (-ae - osoba) jest rodzaju żeńskiego i nie odnosi się jedynie do kobiet. Wedle drugiej koncepcji, przywołanie w nocie o fundacji Pforty informacji o jakimś zgromadzeniu żeńskim w Schmölln mogło wynikać z tego, że w XIII w. w miejscowości tej funkcjonował maryjny ośrodek pielgrzymkowy Unserer Lieben Frau auf dem Berge, znajdujący się prawdopodobnie na miejscu dawnego klasztoru cysterskiego, który został włączony do wspólnoty mniszek z Cronschwitz ${ }^{63}$.

Resztę passusu, w którym padały słowa krytyki względem poprzedników cystersów, autor Exordium zespolił z drugą fundacją w Schmölln benedyktynami ${ }^{64}$. Pojawienie się w opowiadaniu Exordium antagonistów cystersów, a więc benedyktynów, mogło wynikać zatem z faktycznego stanu rzeczy, wiemy przecież o pewnej bliżej nieokreślonej fundacji klasztornej cesarzowej Agnieszki w Schmölln ${ }^{65}$. Jednocześnie benedyktyńskie początki stanowiły bardzo istotny element wielu cysterskich fundationes, na czele z Exordium Parvum. W Exordium monasterii Portensis wprawdzie nie pojawia się zarzut nieprzestrzegania Reguły, jak miało to miejsce w dyplomie biskupa Udona, za to autor noty rozwinął wątek upadku życia zakonnego. Klasztor czarnych mnichów nie tylko nie przynosił żadnych korzyści ani w sprawach duchowych, ani materialnych, ale także coraz bardziej się wyludniał: ,ich konwent został doprowadzony do tak mizernej liczby, iż żyło tam nie więcej niż czterech mnichów wraz z opatem, dlatego też miejsce to wydawało się zupełnie opuszczone" ${ }^{\prime 6}$. Mała liczba mnichów, wyludnienie i opustoszenie wspólnoty oznaczało przede wszystkim, że nie posiada ona Bożej łaski. Wydaje się zresztą, że rozbicie wątku przedcysterskich dziejów Schmölln na historię dwóch zgromadzeń miało potęgować wrażenie, iż to cystersi byli otoczeni szczególną łaską Stwórcy i to sam Bóg chciał fundacji właśnie klasztoru ich ordynacji, stąd też dwa poprzednie zgromadzenia musiały upaść.

W podobny sposób benedyktyńskie początki opisuje autor Exordium monasterii Cara Insula. Cystersi po przybyciu do benedyktyńskiego klasztoru w Weng napotkali tam jedynie trzech mnichów oraz opata.

\footnotetext{
62 W. Corssen, op. cit., s. 33-34.

63 Ibidem, s. 34.

64 UP 1, s. 7.

${ }^{65}$ H. Kunde, Das Zisterzienserkloster Pforte, s. 138.

66 ,ad tantam raritatem personarum redactus est eorum conventus, ut quatuor dumtaxat monachis et abbate superstitibus iam locus destitui videretur", UP 1, s. 7.
} 
W kolejnym opactwie czarnych mnichów, do którego zostali przeniesieni, było już tylko dwóch zakonników ${ }^{67}$. Z kolei nota o fundacji klasztoru cysterskiego w Wörschweiler informuje, że w miejscu przyszłego opactwa znajdowała się najpierw prepozytura czarnych mnichów, w której przebywało jedynie pięciu zakonników. Mieli oni prowadzić lekkomyślne, przyjemne i niedbałe życie, co skutkowało oddaleniem ich przez grafa Ludwika i sprowadzeniem do Wörschweiler cystersów ${ }^{68}$. W Exordium monasterii Portensis pojawia się także topos locus desolatus, a więc miejsca opuszczonego, ruiny ${ }^{69}$. Motyw ten ma swoje źródło w Piśmie św., mianowicie prorok Baruch opisywał Jerozolimę jako ziemię opuszczoną $z$ powodu grzechów narodu wybranego ${ }^{70}$. Podobnie Ezechiel piętnował niewierność Izraela względem Boga i zapowiadał, iż za karę ich ziemia zostanie ogołocona ze wszelkich dostatków i zamieni się w pustkowie ${ }^{71}$. Chociaż sam autor Exordium nie wspomniał bezpośrednio o jakichś uchybieniach obu konwentów, a nawet w nieco retoryczny sposób podkreślał, że nie znany był mu powód upadku opactwa benedyktyńskiego („nescio quo infortunio") ${ }^{72}$, to, jak wiemy, w dokumencie Udona I z 1140 r. znajdowała się wzmianka o nieprzestrzeganiu Reguły przez mnichów ${ }^{73}$. Możliwe zatem, że twórca Exordium poprzez użycie biblijnego motywu w nieco bardziej zawoalowany sposób odwołał się do owych „grzechów”, które spowodowały upadek obu zgromadzeń. W podobny sposób autor Liber Donationum Monasterii Sorensis przedstawił benedyktyńską prepozyturę w Sør. Po odejściu ostatniego z przeorów, Roberta, który miał bardziej troszczyć się o swój żołądek niż duszę, miejsce to stało się całkowicie opuszczone, pozbawione czci. Biskup roskildzki Absalom, chcąc zapobiec upadkowi klasztoru, z inspiracji Ducha św. przekazał go cystersom, którzy jako jedyni mogli przyczynić się do jego rozkwitu ${ }^{74}$. Również graf Bruno widząc, iż jego starania zaszczepienia służby Bożej w Schmölln nie

${ }^{67}$ J. France, op. cit., s. 147.

${ }^{68}$ Regesten des Klosters Werschweiler, wyd. A. Naubauer, Speyer 1921, s. 416-417; T. Trapp, Die Zisterzienserabtei Weiler-Bettnach (Villers-Bettnach) im Hoch- und Spätmittelalter, Saarbrücken 1996, Veröffentlichungen der Komission für Saarländische Landesgeschichte und Volksforschung, t. 27, s. 56.

${ }^{69}$ UP 1, s. 7.

70 Ba $4,12$.

71 „ut desoletur terra a multitudine sua, propter iniquitatem omnium qui habitant in ea. Et civitates quae nunc habitantur, desolatae erunt, terraque deserta, et scietis quia ego Dominus", Ez 12,19-20: http://vulgate.org/ot/ezekiel_12.htm (dostęp: 7 XII 2017).

72 UP 1, s. 7.

73 Ibidem, nr 3.

${ }^{74}$ J. France, op. cit., s. 146. 
przynoszą żadnego efektu, postanowił po rozmowie ze swoim krewniakiem biskupem Naumburga Udonem I sprowadzić na to miejsce cystersów, którzy słynęli w całym świecie chrześcijańskim ze swej pobożności, aby zaprowadzili w Schmölln służbę Bożą ${ }^{75}$.

Kolejne uzupełnienia do wątku o przedcysterskich dziejach Schmölln wprowadził anonimowy autor inskrypcji umieszczonej na południowej ścianie klasztoru. Podtrzymał on wątek o istnieniu w tym miejscu przez przybyciem cystersów dwóch wspólnot, tj. konwentu żeńskiego i klasztoru benedyktyńskiego. Jednak historię pierwszego ze zgromadzeń powiązał ściśle z dziejami rodziny grafa Brunona, a mianowicie jego dzieci - Oetwina i Garburgis. Tragiczna śmierć syna zabitego przez dzika w czasie polowania stała się bodźcem do założenia klasztoru. Motyw ten był zresztą popularny w klasztornych fundationes. Przykładem może być klasztor w Tegernsee. Przyczyną założenia tam klasztoru przez możnych Adalperhta i Otkara była tragiczna śmierć syna tego ostatniego, który, przebywając na dworze króla Pepina, został w czasie zabawy dworskiej zabity przez królewicza. Strata ta tak poruszyła obu braci, że zrzekli się świata i postanowili ufundować klasztor ${ }^{76}$. Chociaż autor noty z Pforty nie wspomina bezpośrednio, tak jak to było w przypadku Tegernsee, iż Bruno ufundował klasztor z powodu śmierci syna, to jednak potwierdzałaby to kolejność przedstawianych przez niego wydarzeń, czyli utrata dziedzica, a następnie fundacja klasztoru, którego opatką została siostra tragicznie zmarłego, a także pochówek młodzieńca w klasztorze.

Ważnym elementem opowiadania o śmierci Oetwina był motyw dzika. W średniowiecznej kulturze zwierzę to było przede wszystkim symbolem zła, szatana, dzikości, porywczości, a także zatwardziałości na słowo Boże ${ }^{77}$. Polowanie na dzika było postrzegane zatem jako walka ze $z_{\text {łem }}^{78}$. Motyw ten pojawia się w m.in. w opowiadaniu o fundacji benedyktyńskiego klasztoru w Ebersberg, gdzie wypędzenie dzika przez protoplastę rodu, fundatora klasztoru grafa Sigiharda, symbolizowało wyrzucenie szatana z ziemi, którą sam Bóg obrał sobie na swoją siedzibę $^{79}$. Przede wszystkim zaś jest to częsty wątek w bawarskich fundationes. W Notae Wessofontanae polowanie na to zwierzę doprowadza księcia bawarskiego Tassilona na miejsce, w którym powstaje później klasztor ${ }^{80}$.

75 UP 1, s. 7.

${ }^{76}$ L. Holzfurtner, op. cit., s. 115.

77 D. Forstner, Świat symboliki chrześcijańskiej, Warszawa 1990 (oryg. niem. 1966), s. 303-304.

${ }^{78}$ J. Kastner, op. cit., s. 117.

79 Ibidem, s. 133-143.

80 Ibidem, s. 105-116. 
Opowiadanie o założeniu klasztoru w Kremsmünster przez Tassilona pod wieloma względami jest podobne do historii Pforty. Tak jak i tam fundatio zaczyna się od opowieści o tragicznej śmierci syna fundatora, Gunthera, który został nieszczęśliwie zraniony w czasie polowania na dzika. Odniesione rany okazały się śmiertelne i młody książę zmarł. O wypadku młodzieńca zaalarmował Tassilona pies, który towarzyszył Guntherowi w czasie polowania. Ojciec, rozpaczając nad ciałem syna, doszedł do wniosku, że w całym tym zdarzeniu objawiła się Boża mądrość. W nocy Tassilonowi, który czuwał nad ciałem syna, ukazał się jeleń z płonącymi świecami między porożem. Zwierzę wskazało władcy miejsce pod założenie klasztoru, w którym pochowany miał zostać Gunther ${ }^{81}$. Jörg Kastner podkreślił w swojej pracy nad klasztornymi historiami fundacyjnymi, że opowiadanie o śmierci młodego księcia miało sens alegoryczny. Tassilon wedle Kastnera symbolizował Boga, Gunther - Chrystusa wysłanego na świat, aby zbawić ludzkość, dzik zaś - szatana, który poprzez śmierć Jezusa został pokonany ${ }^{82}$. W przypadku Pforty dzieje klasztoru również zostały wpisane w walkę dobra ze złem. Podobnie jak w Kremsmünster śmierć Oetwina przyniosła zwycięstwo nad siłami ciemności, gdyż wydarzenie to stało się przyczyną założenia klasztoru, w którym pełniona była służba Boża. Jednocześnie motyw dzika mógł także odwoływać się do dalszych losów Schmölln. Jak wiemy, po dwóch nieudanych fundacjach klasztor objęli cystersi, którzy jednak musieli miejsce opuścić z powodu miejscowej pogańskiej ludności, która nie dość, że nie chciała przyjąć Bożego słowa, to jeszcze terroryzowała mnichów ${ }^{83}$. Dzik zabijający Oetwina symbolizowałby więc ludzi, którzy z uporem trwali w pogaństwie, przyczyniając się do odejścia zakonników do Pforty ${ }^{84}$. Jednak i w tym przypadku zło nie triumfowało, gdyż życie klasztorne rozkwitło w pełni w nowym miejscu.

Prócz Oetwina do klasztornych dziejów została wprowadzona także córka grafa Brunona - mniszka Garburgis ${ }^{85}$. Jej historia wypełniła lukę na temat losów pierwszej wspólnoty klasztornej w Schmölln, o której autor Exordium wspomniał jedynie, iż wraz z upływem czasu zaczęła marnieć i ostatecznie upadła ${ }^{86}$. Wątek Garburgis tym bardziej pasował do dziejów klasztoru, iż w wielu historiach klasztornych wspólnota żeńska fundowana była z myślą o kobietach z rodu fundatora. Za przykład posłużyć może cysterski klasztor Wald ufundowany przez Burkharda Weckensteina

\footnotetext{
${ }^{81}$ Ibidem, s. 105-106.

${ }^{82}$ Ibidem, s. 113-114.

83 UP 1, s. 8.

${ }^{84}$ D. Forstner, op. cit., s. 304.

${ }^{85}$ Wiersz portyjski, s. 76-77.

${ }^{86}$ UP 1, s. 7.
} 
dla jego dwóch sióstr ${ }^{87}$. Podobnie było w przypadku Garburgis, która została ustanowiona opatką ufundowanego przez ojca zgromadzenia ${ }^{88}$. Sporo miejsca autor inskrypcji poświęcił również na scharakteryzowanie jej postaci. Garburgis została przedstawiona jako święta dziewica, podobnie jak służące pod jej zwierzchnictwem mniszki. Jej świętość miała wypełniać radością wszystkich, poczynając od rodziców, poprzez instytucje Kościoła, książąt, a kończąc na szczęściu każdego szlachcica. Również miejsce, w którym został założony klasztor, było święte ${ }^{89}$. W ten sposób najdawniejsze dzieje Schmölln (Pforty) zostały zsakralizowane, ukazano je jako złote czasy, które zakończyła dopiero śmierć świętobliwej opatki.

Obraz ten kontrastował z opisem benedyktyńskich dziejów Schmölln, które stanowiły fazę ostatecznego upadku przedcysterskich fundacji grafa Brunona. Na czarnych mnichów podobnie jak w Exordium spadła fala krytyki, jednak jest ona o wiele bardziej zjadliwa, gdyż autor inskrypcji wprost sugeruje, że zakonnicy zabiegali jedynie o swoje potrzeby, sprawy duchowe zaś zaniedbywali, a nawet, iż próżno było między nimi szukać dobrych mężów ${ }^{90}$. Modyfikacji uległ także passus dotyczący mierności wspólnoty klasztornej. Tak jak autor Exordium stawiał na liczbowy opis obrazujący upadek wspólnoty, w której przebywać miało jedynie czterech mnichów oraz opat, tak twórca tekstu inskrypcji podkreślił raczej jakościowy niedobór szlachetnych mężów. Informację zaś o dokładnej liczebności mnichów przebywających w Schmölln zamienił na wiadomość o pięciu opatach, którzy mieli sprawować władzę nad klasztorem. Ostatni z nich rezydował w opactwie nie dłużej niż miesiąc ${ }^{91}$. Tak częste zmiany na stanowisku opata ukazywały niestabilność wspólnoty, jej wewnętrzne problemy, a także brak odpowiednich ludzi, co może wiązało się z poprzednią wzmianką o niedostatku dobrych mężów. W tekście inskrypcji pojawił się również zupełnie nowy wątek dotyczący pochówku fundatora klasztoru, a także jego żony i dzieci w klasztorze w Schmölln, w którym otaczani byli opieką modlitewną zakonników. Schmölln zostało przedstawione jako nekropolia rodowa grafa Brunona z Pleissengau ${ }^{92}$. Tym samym cystersi, którzy przybyli do Schmölln po mniszkach i benedyktynach, stawali się strażnikami pamięci o Brunonie i jego rodzinie.

87 M. Kuhn-Rehfus, Das Bistum Konstanz, t. 3: Das Zisterzienserinnenkloster Wald, Berlin-New York 1992, Germania Sacra, Neue Folge, t. 30, s. 66.

88 Wiersz portyjski, s. 76.

89 „Eligitur Smolna, fiunt et ibi loca sancta”, ibidem.

90 "Quia sunt dum quaerunt, quae sunt Christi perierunt / Tunc et ibi periere viri cognomine nigri / Sic in his boni vix numerantur ibi", ibidem.

91 Ibidem.

${ }^{92}$ Ibidem, s. 77. 


\section{Trudy początków}

Przedstawienie trudnych początków nowej wspólnoty klasztornej stanowiło jeden z najważniejszych elementów cysterskich tradycji fundacyjnych. Motyw ten pojawił się już w Exordium Parvum, tekście opisującym fundację pierwszego klasztoru cystersów w Cîteaux i był przywoływany w fundationes kolejnych generacji szarych mnichów. W ramach przyjętej konwencji klasztorni autorzy, wzorując się na Exordium, opisywali miejsce pod założenie klasztoru jako locus horribilis, a więc ziemię odludną, porośniętą lasem, zamieszkała przez dzikie zwierzęta ${ }^{93}$. Dopiero dzięki ciężkiej pracy przybyłych na miejsce zakonników, którzy musieli zmagać się z niesprzyjającymi warunkami naturalnymi, biedą, działaniem złośliwych ludzi czy samych demonów, dziki i niebezpieczny teren mógł zostać przekształcony w miejsce zdatne do życia, a przede wszystkim do służby Bożej.

Niektóre przykłady funkcjonowania owego toposu w dziejopisarstwie klasztorów cysterskich położonych na ziemiach zachodnio- i wschodniołabskich przywołał Siegfried Epperlein. Jednym z nich jest mit założycielski opactwa w Loccum. Miejsce pod założenie klasztoru autor Narratio vetus de fundatione monasterii Luccensis a. 1163 opisał jako okropne, całkowicie odludne, zamieszkałe przez zbójów i łotrów. Zdaniem Epperleina za pomocą znanego w literaturze monastycznej toposu twórca vetus narratio zamierzał wyeksponować zasługi szarych mnichów, którzy pomimo przeciwności potrafili zagospodarować posiadane ziemie ${ }^{94}$. Również w tradycji klasztoru portyjskiego wątek trudów początku odgrywał istotną rolę. Po raz pierwszy pojawił się on w klasztornych falsyfikatach dyplomów biskupa Udona I z 1140 i 1145 r. Pierwszy konwent szarych mnichów po przybyciu do Schmölln musiał zmierzyć się nie tylko z niekorzystnymi warunkami naturalnymi, ale przede wszystkim z prześladowaniami miejscowej ludności, określanej mianem barbarzyńców, co ostatecznie zmusiło mnichów do przeniesienia się do Pforty ${ }^{95}$. Wzmiankowani barbarzyńcy to oczywiście ludność słowiańska. Do jej chrystianizacji wezwane były działające na terenie biskupstwa naumburskiego instytucje kościelne. Benedyktyni z klasztoru w Bosau ufundowanego przez biskupa Dietricha mieli w ramach apostolstwa wśród ludności barbarzyńskiej chrzcić,

${ }_{93}$ D. Nahmer, Die Klostergründung ,in solitudine” - ein unbrauchbarer hagiographischer Topos?, „Hessisches Jahrbuch für Landesgeschichte” 22, 1972, s. 90-111.

94 S. Epperlein, „Mit fundacyjny” niemieckich klasztorów cysterskich a relacja mnicha lubiaskiego z XIV wieku, PH 58, 1967, s. 589.

95 UP 1, nr 3. 
wizytować chorych, głosić kazania, chować zmarłych itp. ${ }^{96}$ Podobny zapis znajduje się w dyplomie fundacyjnym kościoła w Plauen z 1122 r. Jego proboszcz został zobowiązany przez biskupa Naumburga do prowadzenia akcji chrystianizacyjnej wśród okolicznej ludności ${ }^{97}$. Wedle dokumentu biskupa Udona z 1140 r. również sprowadzeni do Schmölln cystersi mieli za zadanie chrystianizować pogańską ludność rdzenną. Misja ta nie zakończyła się sukcesem, co nie było jednak winą samych zakonników. Za taki stan rzeczy odpowiadali barbarzyńcy, z powodu których okoliczni mieszkańcy nie przyjęli wiary ${ }^{98}$. Wątek słowiański w nieco krótszej formie znalazł się także w drugim falsyfikacie Udona I z $1145 \mathrm{r}$. Wedle dokumentu akcja chrystianizacyjna zakonników miała wprost odwrotne do oczekiwanych rezultaty. Zamiast sprowadzić miejscowych na drogę wiary, przyniosła ona mnichom prześladowania ze strony barbarzyńców, którzy zakłócali spokój bożym mężom ${ }^{99}$.

W Exordium monasterii Portensis historia o barbarzyńcach została rozwinięta i poszerzona o niżej przytoczoną anegdotę, ukazującą bezpośrednio stopień zagrożenia klasztoru i mnichów ze strony mieszkańców Schmölln. Brak tam wzmianki o jakichś problemach związanych z ziemią, znika również całkowicie wątek chrystianizacji. Uwaga autora koncentruje się na przedstawieniu zagrożenia, jakim dla klasztoru byli Słowianie, którzy zmusili mnichów do opuszczenia Schmölln. Określani są oni jako barbarzyńcy, a więc ludzie obcy kulturowo, którzy reprezentują niższy poziom cywilizacyjny od przybyłych do Schmölln niemieckich zakonników ${ }^{100}$. Autor Exordium określił klasztor jako położony pośród narodu zepsutego i przewrotnego ${ }^{101}$, co przypomina passus z Listu do Filipian, w którym chrześcijanie ukazani są jako światło pośród ludu złego i przewrotnego ${ }^{102}$. Podobnie zakonnicy niosący światło Chrystusa zostali sprowadzeni na ziemię zamieszkałą przez naród zepsuty i przewrotny ${ }^{103}$. Warto dodać, że ten ostatni zwrot był często przywoływany wobec ludności słowiańskiej, czego przykładem może być Kronika Słowian

${ }^{96}$ H. Kunde, Das Zisterzienserkloster Pforte, s. 139.

97 Urkundenbuch des Hochstifts Naumburg (dalej: UHN), t. 1: 967-1207, wyd. F. Rosenfeld, Magdeburg 1925, nr 124.

98 UP 1 , nr 3.

99 „Verum quoniam vix aut nunquam contraria possunt sociari, contigit pravorum persecutione, barbarorum vicinitate quietem eorum perturbari”, ibidem, nr 8 .

100 Ibidem, s. 8; L. Tyszkiewicz, Z badań nad narodzinami stereotypów Słowian $w$ historiografii zachodniej wczesnego średniowiecza, w: idem, Barbarzyńcy w Europie. Studia z późnego antyku i wczesnego średniowiecza, Wrocław 2007, s. 31-53.

101 UP 1, nr 3.

102 Flp 2,15.

103 UP 1, s. 8. 
Helmolda: „Słowianie bowiem z natury są wiarołomni i złośliwi, należy się ich zatem strzec"104.

W odróżnieniu od dyplomów, autor Exordium nie posługuje się tylko zbiorowym obrazem barbarzyńców mieszkających w sąsiedztwie klasztoru, ale przywołuje indywidualny portret jednego z nich, w którym zawiera wiele toposów związanych z przedstawieniem barbarzyńców, a także stereotypów obecnych w niemieckim dziejopisarstwie na temat Słowian ${ }^{105}$. Zabieg ten zwiększa dramaturgię opowiadania, plastyczność opisu, a także pozwala autorowi tekstu mocniej oddziaływać na emocje czytelników. Bohaterem anegdoty jest bogaty Słowianin, który pochował w kościele klasztornym swojego krewnego wbrew woli mnichów, wykorzystując w tym celu nieobecność opata. Kiedy ten ostatni powrócił i dowiedział się o zajściu, kazał wyrzucić z kościoła ciało zmarłego, na którego wcześniej miała zostać nałożona ekskomunika. Jednak w nocy Słowianin wkradł się do klasztoru i ponownie wrzucił ciało krewniaka przez okno kościoła, ukrywającemu się zaś przed nim opatowi groził śmiercią. Zakonnicy udali się ze skargą do biskupa, prosząc go o pozwolenie na powrót do klasztoru macierzystego w Walkenried ${ }^{106}$.

W tym krótkim opowiadaniu autor Exordium zdołał zawrzeć niemal wszystkie stereotypy dotyczące Słowian. Opisany bohater jest przebiegły i podstępny, gdyż, po pierwsze, wykorzystuje dla swojego zamiaru nieobecność opata w klasztorze, po drugie, po porażce udaje, że pogodził się z losem, aby następnie w sprzyjających okolicznościach, czyli w nocnej ciszy, niejako z zaskoczenia, przeprowadzić plan umieszczenia ciała krewnego z powrotem w kościele. Przebiegłość Słowianina zostaje wyeksponowana za pomocą użytego przez twórcę noty toposu ciszy nocnej jako czasu, w którym działa zło. Również pojawiające się w opowiadaniu okienko, przez które zostają wrzucone szczątki, podkreśla podstępność działania, bezprawie, konspirację. W podobnym kontekście okienko jako symbol podstępu pojawia się w historii św. Marcina z Tours w Historii Franków. Po śmierci świętego w Candes między mieszkańcami Poitiers i Tours, z którymi to miastami Marcin był szczególnie związany, rozgorzał spór, gdzie powinien zostać pochowany. Obie strony

104 „Ibi enim statio oportunior fuit et extra pericula posita, eo quod Slavorum animi naturaliter sint infidi et ad malum proni ideoque cavendi", Helmoldus Bozoviensis, Cronica Slavorum (dalej: Kronika Słowian), oprac. B. Schmeidler, MGH SrG, t. 32, Hannover 1937, lib. I, cap. 14, s. 28; przekład polski Helmolda Kronika Słowian, tłum. J. Matuszewski, Warszawa 1974, s. 124.

105 Zob. L. Tyszkiewicz, op. cit., s. 31-53; K. Modzelewski, Barbarzyńska Europa, Warszawa 2004, s. 15-45.

106 UP 1, s. 8. 
w Candes strzegły ciała zmarłego. Pewnej nocy sen zmógł jednak żołnierzy z Poitiers, co wykorzystali ludzie z Tours, wynieśli ciało świętego przez małe okienko i zabrali ze sobą do swego miasta ${ }^{107}$.

Sens obu historii jest oczywiście zupełnie różny. W przypadku szczątków słowiańskiego możnego jego ciało było niemile widziane w kościele, zostało tam siłą umieszczone, a następnie usunięte przez mnichów. W przypadku Marcina jego szczątki niejako także wyrzucono, tj. wykradziono z świątyni, jednak powód takiego działania był zupełnie inny: Marcin był darzony przez ludzi szczególną miłością oraz otaczany kultem. Mielibyśmy zatem do czynienia z antytezą, która jeszcze bardziej uwypukliłaby bezprawie, do jakiego posunął się Słowianin. Czy jednak autor, konstruując omawiany fragment, inspirował się dziełem Grzegorza z Tours? Pewną poszlaką, prócz podobieństwa wątków narracyjnych, są także zbieżności językowe między tekstem Exordium a fragmentem Historii Franków, co jednak nie przesądza jednoznacznie o możliwym wykorzystaniu przez twórcę noty z tekstu Grzegorza z Tours ${ }^{108}$. Postać barbarzyńskiego bohatera Exordium reprezentuje również takie cechy Słowian jak gwałtowność (concitus, plurimum indignatus) czy wpadanie w szał (debachatus), a przede wszystkim okrucieństwo i mściwość ${ }^{109}$. Opis gróźb, jakie pod adresem opata miał miotać barbarzyńca (zabójstwo, rozczłonkowanie i pozostawienie na powolną śmierć), jest zgodny z tym, co o Słowianach pisał Helmold, dla którego lud ten odznaczał się wrodzonym, nigdy nienasyconym okrucieństwem. Szczególną nienawiść Słowianie żywić mieli wobec chrześcijan, których okrutnie torturowali, wbijając na pal czy przybijając do krzyża ${ }^{110}$. Autor Exordium nazwał również Słowianina tyranem, a więc tym, który nie podporządkowuje się prawom, występuje przeciwko legalnej władzy, zakłóca porządek, a także jest osobnikiem zdeprawowanym i zepsutym.

107 Gregorii episcopi Turonensis Libri historiarum X (dalej: Historia Franków), wydanie II, wyd. B. Krusch, W. Levison, Hannoverae 1951, MGH SS rer. Merov. 1.1, lib. I, cap. 48, s. 33.

108 Por. „Super quo facto plurimum indignatus Slavus acceptam corporis glebam concitus retulit intempeste noctis silentio per fenestram iniciens ecclesie", UP 1, s. 8; „Denique nocte media omnes Pectava somno falanga conpraemitur, nec ullus superfuit, qui ex hac multitudine vigilaret. Igitur ubi Toronici eos conspiciunt obdormisse, adpraehensam sanctissimi corporis glebam, alii per fenestram eiciunt [wyróżnienia - M.M.]", Historia Franków, s. 33.

109 „ut ipsum tamquam auctorem effossi cadaveris (opata) crudeli animadversione puniret, seu vita privaturus, sive mutilato aliquo membro seminecem relicturus", UP 1, s. 8.

110 Kronika Słowian, lib. I, cap. 52, s. 103. 
W podobny sposób niemieccy kronikarze nazywali polskich władców Bolesława Chrobrego czy Mieszka II ${ }^{111}$. W przypadku Pforty Słowianin został nazywany tyranem, gdyż naruszał spokój wspólnoty, której prawnym opiekunem był biskup Udo I. Hierarcha martwił się zastałą sytuacją, ponieważ lud mógłby posądzić go o to, iż nie potrafi obronić swoich przed wrogami ${ }^{112}$.

Autor Exordium za pomocą anegdoty o podstępnym i okrutnym Słowianinie uwypuklił fizyczne zagrożenie klasztoru, które tłumaczyło i usprawiedliwiało decyzję mnichów o opuszczeniu Schmölln. Wydaje się również, że opowiadanie to mogło mieć swoje źródło w prawdziwych wydarzeniach i zostać zaczerpnięte z tradycji ustnej klasztoru bądź też było echem wydarzeń, które miały miejsce czy to w najbliższym sąsiedztwie mnichów, czy też dalszym. Mianowicie Ekkehard von Aura w swojej kronice świata, ukończonej ok. 1125 r., opisał śmierć biskupa Naumburga Dietricha I z ręki pogan w 1123 r. ${ }^{113}$ Biskup był założycielem benedyktyńskiego klasztoru w Bosau, do którego byli przyjmowani jako konwersi także Słowianie. Opat i biskup Dietrich chcieli podporządkować ich regułom życia klasztornego, co napotkało jednak na opór. Jeden z nich, określony jako przewrotny (perversus), nie chcąc przyjąć przewidzianych przez biskupa kar, zabił go przy ołtarzu. Na miejscu zbrodni powstał nagrobek biskupa upamiętniający to wydarzenie. W dyplomie z $1147 \mathrm{r}$. dla mniszek w Zeitz Udo I wspomniał o swoim poprzedniku - Dietrichu i jego dziele zaszczepienia wiary w dzikim i nieokrzesanym ludzie, co przyniosło mu śmierć114.

Historia mordu na Dietrichu pojawiała się także w późniejszych źródłach, m.in. w dziełku mistrza Jordana z XIV w. o cudach maryjnych czy w Historia fundationis monasterii Bosaugiensis, w której podane zostaje nawet imię owego konwersa - Benno oraz jego pochodzenie z ludu Serbołużyczan ${ }^{115}$. Los Dietricha był udziałem wielu opatów i zakonników z klasztorów cysterskich usytuowanych na ziemiach zamieszkałych bądź graniczących z ludnością słowiańską. Przykładem może być leżący w Meklemburgii klasztor Doberan. W 1179 r. został on zniszczony przez Słowian, w czasie najazdu zginąć miało 78 mnichów ${ }^{116}$. Do podobnych wydarzeń doszło także $\mathrm{w}$ brandenburskim klasztorze Lehnin, gdzie

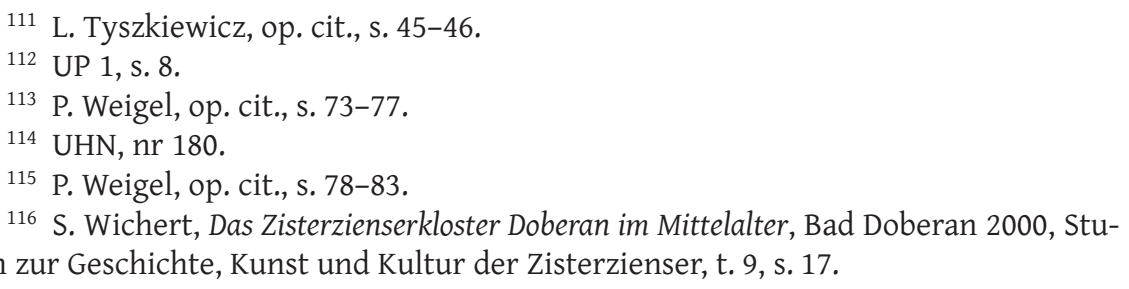


w 1185 r. został zamordowany pierwszy opat klasztoru Sibold ${ }^{117}$. Ofiarą Kurów i Semigallów stał się z kolei łotewski klasztor Dünamünde (Daugavgrīva $)^{118}$. Jako że w 1239 r. Kapituła Generalna ustanowiła Pfortę macierzą Dünamünde, stąd też wieści o napadzie barbarzyńców w 1228 r. i wymordowaniu mnichów musiały być dobrze znane w portyjskim opactwie ${ }^{119}$.

Jednak anegdota o bogatym Słowianinie dowodziła nie tylko bezpośredniego zagrożenia życia mnichów w Schmölln, ale także niebezpieczeństwa dla życia duchowego wspólnoty. W kościele klasztornym doszło do pochówku ekskomunikowanego, co było surowo zabronione przez władze kościelne, które odpowiedzialnych za tego rodzaju praktyki karały ekskomuniką latae sententia ${ }^{120}$. Sankcje były uchylane dopiero wtedy, gdy ciało ekskomunikowanego zostało ekshumowane i przeniesione na niepoświęcone miejsce. W pierwszej części Catalogus Abbatum Saganensium Ludolfa z Żagania z końca XIV w. znajduje się opis zagrożeń dla życia wewnętrznego wspólnoty, jakie na konwent kanoników ściągnął pochówek księcia żagańsko-głogowskiego Henryka VIII Wróbla ${ }^{121}$. Władca miał umrzeć w trakcie sprawy toczonej przed sądem kościelnym z kanonikiem głogowskim Mikołajem, która zakończyła się obłożeniem zmarłego ekskomuniką przez biskupa wrocławskiego. Księcia jeszcze jako wolnego od klątwy kościelnej pochowano w kościele klasztornym ${ }^{122}$. Ogłoszenie ekskomuniki przyniosło bardzo negatywne skutki dla opactwa. Kościół i cmentarz klasztorny zostały uznane za nieczyste. Sytuacja ta ciągnęła się od marca do grudnia 1397 r. Msze św. w klasztorze odprawiano przy przenośnych ołtarzach w refektarzach. Sam kościół musiał zostać poddany rytuałowi oczyszczenia poprzez ponowne poświęcenie go przez biskupa, nastąpiła także ekshumacja ciała władcy, który leżał poza grobem przez osiem dni ${ }^{123}$. Niebezpieczeństwo uznania kościoła klasztornego za nieczysty istniało także w Schmölln. Chociaż pochówek Słowianina z nałożoną anatemą został dokonany bez zgody mnichów, a opat

117 S. Warnatsch, Geschichte des Klosters Lehnin, 1180-1542, Berlin 2000, Studien zur Geschichte, Kunst und Kultur der Zisterzienser, t. 12, s. 52-55.

118 H. Kunde, Das Zisterzienserkloster Pforte, s. 243.

119 Ibidem, s. 244.

120 B. Wojciechowska, Ekskomunikowani w świetle średniowiecznego prawa kanonicznego - pozycja społeczna, religijna i prawna, „Studia Historica Gedanensia” 4, 2013, s. 29.

121 Catalogus abbatum Saganensium, wyd. G.A. Stenzel, w: Scriptores rerum Silesiacarum oder Sammlung schlesischer Geschichtsschreiber, t. 1, Wrocław 1835, s. 238-241; A. Filipek-Misiak, Ksiażę, opat, pochówek. Władza księcia a władza opata w świetle Catalogus Abbatum Saganensium Ludolfa z Żagania, w: Potestas et societas. Władza w średniowiecznej Europie, red. P. Wiszewski, J. Wojtkowiak, Wrocław 2014, s. 13-21.

122 A. Filipek-Misiak, op. cit., s. 15-16.

${ }^{123}$ Ibidem, s. 17-18. 
natychmiast po swoim powrocie do klasztoru podjął przewidziane w prawie kanonicznym kroki, tj. ekshumował ciało zmarłego, to kolejne działania podejmowane przez krewniaka zmarłego, który postanowił ponownie umieścić jego zwłoki w kościele, niosły za sobą takie zagrożenie ${ }^{124}$.

Za pomocą anegdoty o bogatym Słowianinie autorowi Exordium udało się nie tylko podnieść walor literacki swojego tekstu, ale przede wszystkim uzasadnić powód przenosin mnichów z Schmölln do Pforty. Tragizm sytuacji, w jakiej znaleźli się zakonnicy, podkreślała także zapowiedź ich powrotu do macierzystego klasztoru w Walkenried. Dla biskupa Udona I odejście braci z Schmölln do macierzy oznaczałoby uszczerbek dla autorytetu władzy biskupiej ${ }^{125}$. W klasztornych opowieściach o trudach początków groźba powrotu mnichów do klasztoru macierzystego stanowiła częsty motyw. W falsyfikacie henrykowskim z $1229 \mathrm{r}$. z podobną sytuacją spotkał się Henryk Brodaty, któremu mnisi z Henrykowa zagrozili powrotem do Lubiąża, jeżeli nie odzyskają klasztornego majątku przekazanego przez księcia Stefanowi z Kobylej Głowy. Miałoby to sprowadzić na niego Boży gniew ${ }^{126}$. Fragment ten ukazuje, iż zawiniony przez opiekuna upadek fundacji, a co za tym idzie służby Bożej na wybranym przez samego Stwórcę miejscu, prowadził do ukarania winowajcy.

Ślad tego typu rozumowania widoczny jest również w opowiadaniu o fundacji angielskiego klasztoru Forde, założonego w 1133 r. przez Richarda de Brioniis ${ }^{127}$. Jednak ziemia, którą mnisi dostali od swojego fundatora, była nieurodzajna, przez co cierpieli srogi głód, niewygodę, szczególnie po śmierci możnowładcy ${ }^{128}$. Wtedy też zakonnicy zdecydowali się opuścić klasztor i powrócić do macierzy w Waverley. Idących boso braci spotkała jednak siostra Richarda - Adelicia. Gdy dowiedziała się o ruinie fundacji brata, chcąc przeciwdziałać niebezpieczeństwu, jakim był upadek klasztoru założonego przez Richarda ku chwale Boga, zaproponowała zakonnikom inną ziemię, byle tylko pozostali ${ }^{129}$. W historii klasztoru w Forde chodzi przede wszystkim o zagrożenie dla duszy założyciela, który poprzez upadek swojej fundacji byłby pozbawiony modlitwy

124 UP 1, s. 8.

125 Ibidem.

126 Schlesisches Urkundenbuch, t. 1: 971-1230, wyd. H. Appelt, Wien-Köln-Graz 1971, nr 371.

127 Fundationis et Fundatorum Historia, w: Monasticon Anglicanum. A History of the Abbies and Other Monasteries, cz. 5, wyd. W. Dugdale, Londyn 1846, s. 377-378; S. Heath, The Story of Ford Abbey. From the Earliest Times to the Present Day, London 1911, s. 25-26.

128 Fundationis et Fundatorum Historia, s. 378.

129 Ibidem. 
zakonników i samej zasługi. Wszystkie trzy przykłady: Pforty, Henrykowa i Forde ukazują, iż fiasko fundacji postrzegane było jako ujma na honorze, upadek autorytetu fundatora i niosło ze sobą także gniew Stwórcy.

\section{Macierz klasztoru portyjskiego}

W przypadku Pforty temat domu macierzystego, a więc klasztoru w Walkenried, pojawił się już w falsyfikatach dyplomów biskupa Udona I z 1140 i $1145 \mathrm{r}$. W pierwszym z dokumentów odnotowano nazwę klasztoru matki, a także podkreślono trud włożony przez Udona w pozyskanie mnichów z Walkenried ${ }^{130}$. Wątek ten został rozwinięty w dyplomie z $1145 \mathrm{r}$. Oprócz nazwy klasztoru macierzystego zostaje także przywołane imię opata Walkenried, Henryka, z którym biskup Udo pertraktował w sprawie sprowadzenia cystersów na teren swojej diecezji. Dyktator dokumentu zaakcentował także udział Stwórcy, zarówno w pojawieniu się intencji fundacji domu cysterskiego u biskupa Udona, jak i w uzyskaniu przez niego, po wielu prośbach, zgody opata Henryka na wysłanie konwentu mnichów do Schmölln ${ }^{131}$.

Obraz macierzy klasztoru portyjskiego został uzupełniony o nowe szczegóły przez autora Exordium. Zawarł on na kartach swojego dzieła nie tylko pochwałę Walkenried, ale także wyjaśnił powód, dla którego to właśnie ten klasztor został przez Udona wybrany na dom macierzysty Schmölln/Pforty. Do nawiązania kontaktów między biskupem i klasztorem cystersów w Walkenried doszło w wyjątkowych okolicznościach, tj. w trakcie podróży tego duchownego wraz z kanonikiem Hartmannem do Hildesheim na kanonizację biskupa Gotarda ${ }^{132}$. Chociaż autor Exordium nie pisze wprost o jakiejkolwiek interwencji św. Gotarda w fundację, to jednak przedstawiony przez niego proces przyczynowo-skutkowy, który doprowadził do założenia klasztoru, a więc: wyjazd Udona na kanonizację do Hildesheim, zatrzymanie się w takcie podróży na wypoczynek w Walkenried, podjęcie decyzji o założeniu domu szarych

130 UP 1, nr 3.

131 Ibidem, nr 8.

132 Ibidem, s. 8. Obecności Udona I w czasie kanonizacji w 1132 r. nie potwierdza jednak żaden przekaz źródłowy (H. Kunde, Das Zisterzienserkloster Pforte, s. 149-150). Na taką możliwość wskazywałoby jednak posiadanie przez Pfortę relikwii świętego. W spisie relikwii prepozyta Waltera von Ichtershausen znajduje się wzmianka o zawiązaniu braterstwa między Pfortą i Ichtershausen w $1173 \mathrm{r}$. Z tej okazji portyjscy mnisi podarowali cysterkom z Ichtershausen relikwie św. Gotarda (H. Kunde, Das Zisterzienserkloster Pforte, s. 270). 
mnichów w diecezji naumburskiej, wskazuje, iż celem twórcy fundatio było przekonanie czytelnika o udziale sił nadprzyrodzonych w powstaniu Schmölln/Pforty. Twórca Exordium rozwinął zatem myśl zawartą w dyplomie Udona I z 1145 r. W jego przekazie to niejako sam Bóg za pośrednictwem św. Gotarda przywiódł biskupa do Walkenried.

Wybór ten podyktowany był sposobem życia mnichów w Walkenried, który zachwycił biskupa Udona ${ }^{133}$. W ten sposób autor Exordium dokonał pochwały macierzy i utrwalił jej obraz w tradycji opactwa, co było zresztą charakterystyczną cechą fundationes. Podobna historia o wyborze klasztoru macierzystego w czasie podróży fundatora występuje również w tradycji samego Walkenried, utrwalonej w kronice opactwa w Kamp ${ }^{134}$. Fundatorką była Adelajda von Klettenberg, która po wstąpieniu swojego męża i syna do zakonu postanowiła ufundować z posiadanego przez siebie majątku klasztor. Początkowo miał być benedyktyński, obsadzony przez mnichów z Huysburgu, gdzie służyli jej najbliżsi, jednak opat tegoż miejsca nie wyraził zgody na wysłanie mnichów ${ }^{135}$. Podczas podróży do Nadrenii z Bożej inspiracji Adelajda spotkała cystersów z Kamp, których pobożność ją zachwyciła ${ }^{136}$. Postanowiła więc ufundować ich klasztor, prosząc pokornie Kamp o konwent. Kronika, w której znajduje się opowiadanie o podróży Adelajdy, pochodzi jednak z początków XVI w., tak więc trudno stwierdzić, czy funkcjonowała wcześniej w filii Kamp - Walkenried i czy zainspirowała autora Exordium do przywołania podobnego motywu. Również w fundatio klasztoru w Wörschweiler mamy zbliżoną historię o wyborze macierzy dla klasztoru. Graf Ludwik, będąc w Metzu, spotkał opata z Weiler-Bettnach i sposób jego życia oraz podejmowane działania spodobały się mu tak bardzo, że zapragnął sprowadzić do siebie mnichów cystersów z tego właśnie klasztoru ${ }^{137}$.

Autor Exordium właściwe negocjacje między biskupem Udonem a opatem Walkenried w przeciwieństwie do twórcy falsyfikatów opisał bardzo sucho. Stwierdził jedynie, iż biskup pokornie poprosił na osobności Henryka o mnichów do swojej planowanej fundacji, na co ten ostatni się zgodził ${ }^{138}$. Twórca Exordium zrezygnował całkowicie z zaakcentowania

133 UP 1, s. 8.

134 H. Keussen, Chronicon monasterii Campensis ordinis Cisterciensis, w: Fontes adhuc inediti rerum Rhenanarum. Niederrheinische Chroniken, cz. 2, wyd. G. Eckertz, Köln 1870, s. $329-428$.

135 N. Heutger, Kloster Walkenried. Geschichte und Gegenwart, Berlin 2007, Studien zur Geschichte, Kunst und Kultur der Zisterzienser 27, s. 18-21.

${ }^{136}$ H. Keussen, op. cit., s. 333.

137 Regesten des Klosters Werschweiler, s. 416-417.

138 UP 1, s. 8. 
trudów, jakie Udo włożył w uzyskanie od opata Walkenried zakonników do swojej fundacji w Schmölln.

W nocie o fundacji klasztoru poświęcono także osobny passus na przedstawienie przygotowań Udona I do sprowadzenia cystersów. Miał on $\mathrm{w}$ tej sprawie naradzić się ze swoją kapitułą, która jednoznacznie wyraziła zgodę na sprowadzenia zakonników z Walkenried. Dopiero po tym fakcie pojechał on po mnichów ${ }^{139}$. Wydaje się, że owe podkreślenie zgody kapituły naumburskiej, które pada raz jeszcze w przywołaniu obowiązku zadośćuczynienia opactwu za starty przy translokacji z Schmölln do Pforty, stanowi echo sporu klasztoru z biskupem Engelhardem i jego kapitułą. Samo wyjście zakonników z Walkenried nie zostało szerzej opisane, tak jak miało to miejsce chociażby w przypadku Viktring, gdzie autor dość obrazowo ukazał pożegnanie mnichów przez ich współbraci, któremu towarzyszyły śpiewy i łzy ${ }^{140}$. Pierwszy konwent do Schmölln miał być osobiście prowadzony przez biskupa Udona ${ }^{141}$.

\section{Translokacja}

Zmiana pierwotnej lokalizacji klasztoru we wczesnym etapie implantacji wspólnoty klasztornej stanowiła wedle badań Hansa Niedermaiera częste zjawisko ${ }^{142}$. Powody, dla których mnisi przenosili się na nowe miejsce, były różnorodne. Zazwyczaj wiązały się z niedogodnościami mającymi swoje źródło w warunkach naturalnych bądź też w konfliktach z miejscową ludnością czy też z innymi instytucjami kościelnymi ${ }^{143}$. Poszukiwanie przez zakonników miejsca pod klasztor lub następnie jego przenosiny stanowiło również niezwykle ważny motyw w tradycjach fundacyjnych ${ }^{144}$.

W przypadku interesującego nas zgromadzenia pierwszym źródłem, które informowało o jego translokacji z Schmölln do Pforty, była bulla Innocentego II z 1138 r. Papieski dyplom na prośbę opata Adalberta zatwierdzał zamianę dóbr dokonaną między biskupem Udonem I

139 Ibidem.

140 J. Kastner, op. cit., s. 64.

141 UP 1, s. 8.

${ }^{142}$ H. Niedermaier, Klostertranslationen bei den Zisterziensern, „Cîteaux” 24, 1973, s. 31-52.

143 Ibidem.

${ }^{144}$ W. Schich, Klosteranlage und Wasserversorgung bei den Zisterziensern, w: Wirtschaft und Kulturlandschaft. Gesammelte Beiträge 1977 bis 1999 zur Geschichte der Zisterzienser und der „Germania Slavica”, red. idem, Berlin 2007, s. 181. 
a cystersami ${ }^{145}$. Temat translokacji klasztoru rozwinęły falsyfikaty portyjskie. Najszerzej został on potraktowany w dyplomach z 1140 i 1145 r. Dokument z 1140 r. wyjaśniał powody przenosin klasztoru do Pforty, którymi były ciężkie warunki naturalne panujące w Schmölln, sąsiedztwo barbarzyńców, którzy dokuczali mnichom oraz brak sukcesów klasztoru w ich chrystianizacji. Wedle dyktatora dokumentu translokacja została dokonana za radą i wolą króla Konrada III, książąt i kapituły naumburskiej. Akt przenosin opactwa potwierdził także papież Innocenty II $^{146}$. Treść falsyfikatu z 1145 r. zawiera pewne zmiany w stosunku do pierwszego dyplomu. Brak w nim informacji o niedogodnościach pierwotnego miejsca, jak i wzmianki o zgodzie króla Konrada III i książąt na zamianę ziem między mnichami a Udonem. Podaje on natomiast zupełnie nową wiadomość dotyczącą aktywnej roli zakonników w translokacji opactwa do Pforty. Oni sami mieli zwrócić się do biskupa ze skargami na trudną sytuację w Schmölln i prosić go o pomoc. We wszystkich ośmiu falsyfikatach (dwa z 1140, 1145, 1168, 1180, 1205, 1205, 1207) zaznaczono, iż ziemie otrzymane przez mnichów w Pforcie były uboższe niż te, które zakonnicy posiadali pierwotnie w Schmölln. Dlatego też biskup Udo I zobowiązał samego siebie, a także swoich następców do wynagrodzenia mnichom tej straty z majątku biskupstwa. Ponadto w dyplomie Udona I (1140) znajduje się jeszcze passus, w którym podkreślono, iż opactwo zostało pierwotnie ufundowane na wolnej ziemi, przez wolnego wielmożę, stąd też biskup, dokonując przenosin konwentu do Pforty, miał zobowiązać się do przestrzegania wolności, którymi klasztor cieszył się w Schmölln. Pojawia się także zapis o zobowiązaniu się biskupa do przestrzegania przywilejów, jakie posiadał zakon cysterski. $\mathrm{W}$ dokumencie z 1145 r. doprecyzowano, iż biskup potwierdza opactwu wszelkie wolności, jakie wynikają z przywilejów ich zakonu, pozostawia sobie jedynie te prawa, które wedle szarych mnichów przynależą biskupom diecezjalnym ${ }^{147}$. Warto zaznaczyć, iż wątek przenosin klasztoru na nowe miejsce został w falsyfikatach rozbudowany z bardzo konkretnego powodu. Był nim spór Pforty z biskupem Naumburga Engelhardem I dotyczący klasztornego majątku. Pojawiająca się w nich klauzula, która dotyczyła zobowiązania kolejnych ordynariuszy katedry naumburskiej do udzielenia mnichom ekwiwalentu, stanowiła rodzaj obrony stanu posiadania klasztoru.

Autor Exordium jako jedyny motyw translokacji klasztoru przywołał zagrożenie ze strony okolicznych barbarzyńców. Idąc za przekazem

145 UP 1, nr 2.

146 Ibidem, nr 3, 8.

147 Ibidem, nr 8. 
dyplomu z 1145 r., podkreślił aktywną rolę mnichów w podjęciu decyzji o przenosinach. Zakonnicy nie tylko wnosili skargi na zastaną w Schmölln sytuację, ale także zagrozili powrotem do Walkenried. Chcąc temu zapobiec, biskup Udo zaproponował cystersom, aby wybrali sobie jakiś inny teren pod klasztor w kluczu jego dóbr ${ }^{148}$. Exordium opisuje objazd biskupich ziem przez zakonników, którzy oglądali i oceniali poszczególne majątki. Wiele z nich odrzucili ze względu na jałowość ziemi bądź jakieś inne skazy. Zaakceptowali dopiero Pfortę, uzyskując tam 50 łanów ziemi ${ }^{149}$. Opowiadanie to ukazuje wyjątkowość Pforty, spełniającej wszystkie stawiane przez zakonników wymogi, którą mnisi znaleźli po wielu podróżach i wybrali spośród licznych ziem należących do biskupa Udona. Podobny motyw wędrówki za nowym miejscem pod klasztor ukazuje Exordium monasterii quod dicitur Cara Insula, chociaż sam przebieg translokacji klasztoru jest o wiele bardziej dramatyczny niż w przypadku Schmölln (Pforty) ${ }^{150}$. Mnisi uzyskali od swojego fundatora, duńskiego biskupa Eskilda z Arhus (Aarhus), ziemię w Sabro, która po pewnym czasie okazała się jednak nieodpowiednia i otrzymali w zamian miejscowość Sminge, równie ubogą co Sabro. Z pomocą następcy Eskilda, biskupa Svena, zakonnicy zostali przeniesieni do Veng, które opuścili z powodu konfliktu z miejscową szlachtą. Następnie udali się na wyspę Kalvø, nienadającą się do pełnienia służby Bożej z powodu srogich zim, i ostatecznie zawędrowali do Øm, gdzie już zostali ${ }^{151}$. Należy dodać, iż autor Exordium całkowicie pominął w swoim opowiadaniu informację na temat zatwierdzenia zmiany ziem między Udonem a klasztorem przez Konrada III i Innocentego II, co stanowiło przecież pewnego rodzaju gwarancję postanowień zawartych między mnichami a biskupem, a także wskazywało na udział w procesie fundacyjnym klasztoru obu filarów świata chrześcijańskiego. Wydaje się, iż ważniejsze było dla autora odnotowanie zgody na ten akt kapituły naumburskiej, co stanowiło echo sporu z biskupami tej katedry. Podobnie jak klasztorne falsyfikaty, Exordium zawierało także passus dotyczący zobowiązana biskupów Naumburga do przekazania mnichom ekwiwalentu za Schmölln, który został przejęty niemal dosłownie z dyplomu z $1140 \mathrm{r}$.

\footnotetext{
148 Ibidem, s. 9.

149 Ibidem.

150 J. France, op. cit., s. 120-121.

151 B.P. McGuire, Conflict and Continuity at Øm Abbey. A Cistercian Experience in Medieval Denmark, Copenhagen 1976, s. 27-42
} 
Ekskurs: tradycja lubiąska

Chociaż treść tradycji fundacyjnej zależała od specyficznych oraz unikatowych dla każdej wspólnoty klasztornej uwarunkowań, tj. czasu powstania opactwa, miejsca założenia klasztoru, okoliczności politycznych i społecznych, a przede wszystkim od postaci samego fundatora, to przybywający na nowe miejsce zakonnicy przynosili jednak ze sobą pewne wzorce postrzegania przeszłości, a także środki, za pomocą których możliwe było jej utrwalanie, mające swoje źródło w klasztorze macierzystym. W przypadku cystersów kontakty z opactwem matką nie ograniczały się jedynie do wysłania konwentu na nowe miejsce. Dzięki więziom filiacyjnym owe relacje były podtrzymywane i pielęgnowane, zapewniając tym samym przepływ informacji między klasztorami. Stąd też zasadne jest postawienie pytania, czy omawiana powyżej tradycja fundacyjna klasztoru portyjskiego wywarła jakikolwiek wpływ na wyobrażenia owłasnej przeszłości śląskiej filii Pforty - opactwa w Lubiążu założonego w 1163 r. przez powracającego z wygnania księcia Bolesława Wysokiego ${ }^{152}$.

W czasie, kiedy mnisi portyjscy zintensyfikowali swoje prace nad utrwaleniem tradycji fundacyjnej za pomocą kopiarza wraz z zawartym w nim Exordium monasterii Portensis, widoczny jest także wzrost zainteresowania własną przeszłością w Lubiążu. W skryptorium lubiąskim za rządów opata Teodoryka (1284-1304), podobnie jak miało to miejsce kilkadziesiąt lat wcześniej w Pforcie, doszło do powstania kilku falsyfikatów najstarszych dyplomów wystawionych na rzecz opactwa ${ }^{153}$. Jednym ze sfałszowanych wówczas dyplomów był dokument fundacyjny Bolesława Wysokiego z 1175 r. Przyczyną dokonania fałszerstwa była chęć zapewnienia sobie przez zakonników praw do posiadanego majątku ${ }^{154}$.

152 Zob. O. Górka, Studya nad dziejami Ślaska. Najstarsza tradycja opactwa Cystersów w Lubiażu, Lwów 1911; K.K. Jażdżewski, Lubiaż. Losy i kultura umysłowa ślaskiego opactwa cystersów (1163-1642), Wrocław 1992; W. Könighaus, Die Zisterzienserabtei Leubus in Schlesien von ihrer Gründung bis zum Ende des 15. Jahrhunderts, Wiesbaden 2004, Quellen und Studien. Deutsches Historisches Institut Warschau, t. 15.

${ }^{153}$ K.K. Jażdżewski, Poglądy średniowiecza na fałszowanie dokumentów (w związku z czterema falsyfikatami przywileju fundacyjnego dla cystersów w Lubiażu z 1175 roku), „Sprawozdania Wrocławskiego Towarzystwa Naukowego" 33, 1978, s. 66-71; P. Wiszewski, Nowe jak stare, czyli o tradycji z falsyfikatów lubiaskiego dokumentu fundacyjnego (XIII-XIV w.), w: Stare i nowe $w$ średniowieczu. Pomiędzy innowacja a tradycja, red. S. Moździoch, Wrocław 2009, s. 411-427; M. Kaczmarek, W sprawie falsyfikatów lubiaskich raz jeszcze, w: Memoria viva. Studia historyczne poświęcone pamięci Izabeli Skierskiej (1967-2014), red. G. Rutkowska, A. Gąsiorowski, Poznań-Warszawa 2015, s. 190-206, zwłaszcza s. 201-202.

${ }^{154}$ H. Appelt, Urkundenfälschungen in Schlesien, w: Fälschungen im Mittelalter. Internationaler Kongress der Monumenta Germaniae Historica München, 16.-19. September 1986, Hannover 1988, MGH. Schriften, t. 33, cz. 4, s. 542-545. 
Przy okazji aktualizowania stanu majątkowego klasztoru dokonali oni także rewizji znanej z pisma księcia tradycji fundacyjnej własnej wspólnoty. Pojawiły się w niej zupełnie nowe elementy, do których zalicza się przede wszystkim motyw benedyktyńskich dziejów lubiąskiej wspólnoty. Wedle falsyfikatu przed cystersami w Lubiążu przebywała niewielka wspólnota czarnych mnichów, która została przez Bolesława Wysokiego zastąpiona zakonnikami z Pforty ${ }^{155}$. Chociaż motyw benedyktyńskich początków występował dość często w tradycjach fundacyjnych opactw cysterskich, to warto wspomnieć, iż w tym samym czasie co w Lubiążu wątek czarnych mnichów pojawił się również w klasztorze portyjskim na kartach Exordium monasterii Portensis.

Kolejnym novum w falsyfikacie dyplomu książęcego z 1175 r., który mógł pojawić się pod wpływem Pforty, była wzmianka o bezpośrednim zaangażowaniu w proces fundacji klasztoru biskupa wrocławskiego i jego kapituły, na których to prośbę Bolesław Wysoki sprowadził do Lubiąża szarych mnichów ${ }^{156}$. Najpewniej fałszerz dyplomu fundacyjnego chciał w ten sposób wyeksponować bliskie relacje łączące biskupów wrocławskich z klasztorem, co z jednej strony być może odzwierciedlało rzeczywiste stosunki panujące $\mathrm{w}$ czasach spisania dyplomu, a więc $u$ końca XIII w., między biskupem Tomaszem II a opatem Teodorykiem, a z drugiej miało zapewne na celu także projektowanie przyszłości wspólnoty klasztornej, wspieranej przez kolejnych hierarchów wrocławskich ${ }^{157}$. Pewną inspiracją w tym przypadku mogła być również tradycja portyjska, w której pierwszoplanową rolę odgrywał biskup Naumburga Udo I.

Także w późniejszych tekstach lubiąskich można dostrzec pewne echa opowiadania o założeniu Pforty. W spisanym w XIV w. Versus Lubenses pojawia się wątek zapóźnionej cywilizacyjnie, pogańskiej ludności zamieszkującej miejsce, gdzie został założony klasztor ${ }^{158}$. Motyw

155 Schlesisches Urkundenbuch, t. 1: 971-1230 [dalej: SUB 1], wyd. H. Appelt, J.J. Menzel, Köln 1963, nr 325.

156 Ibidem.

157 W. Könighaus, op. cit., s. 293-294.

${ }^{158}$ Monumenta Lubensia, wyd. W. Wattenbach, Breslau 1861, s. 14-15; M. Cetwiński, „Ara demonis”. Od pogańskiego miejsca kultu do cysterskiego klasztoru w Lubiążu, w: Kulturotwórcza rola cystersów na Kociewiu. Pelplin - 725 rocznica powstania opactwa cysterskiego. Materiały z sesji naukowej zorganizowanej w Pelplinie w dniach 21-23 września 2001 r., przez Starostwo Powiatowe w Tczewie, Instytut Historii Uniwersytetu Gdańskiego oraz Zespółdo badań nad historia i kultura cystersów w Polsce Uniwersytetu Adama Mickiewicza w Poznaniu, red. D.A. Dekański, Pelplin 2002, s. 101-105. 
ten przypomina w ogólnych zarysach historię o złośliwych Słowianach z portyjskiego Exordium.

Nowe wątki dotyczące najdawniejszych dziejów lubiąskiej wspólnoty, które pojawiły się w falsyfikacie dokumentu Bolesława Wysokiego z 1175 r., nie pozwalają oczywiście na bezsprzeczne powiązanie ich z klasztorem w Pforcie. Warto jednak w tym miejscu przywołać jeszcze jeden falsyfikat lubiąski, który chociaż nie wnosi nic nowego do obrazu fundacji opactwa, to rzuca nieco światła na to, w jakim stopniu tamtejszym zakonnikom znane były wytwory skryptorium klasztoru macierzystego. Chodzi o falsyfikat dokumentu księcia Bolesława Wysokiego z 1201 r., w którym władca ten miał potwierdzić mnichom z Lubiąża 1000 łanów na terenie księstwa opolskiego między Osobłogą a Stradunią wraz z dziesięcinami, które mnisi z Pforty otrzymali od księcia Jarosława na rzecz nowej fundacji cysterskiej, a po jego śmierci przekazali wzmiankowane dobra swojej śląskiej filii ${ }^{159}$. W dyplomie tym rzuca się w oczy niewystępująca w oryginalnych dyplomach informacja o ogromnej liczbie łanów, które lubiąscy zakonnicy mieli otrzymać. Co ciekawe, niemal identyczna wzmianka występuje w Exordium monasterii Portensis. Jak pamiętamy, graf Bruno przekazał na ręce biskupa Udona nie tylko Schmölln, ale także wiele wsi, których powierzchnia miała wynosić 1100 łanów. O możliwości korzystania przez lubiąskiego mnicha z źródeł portyjskich może świadczyć fakt, iż arenga dyplomu-falsyfikatu przypomina, wedle badań Heinricha Appelta, preambułę jednego z dokumentów klasztoru w Pforcie, który datowany jest na lata 1264-1271 i został wciągnięty do klasztornego kopiarza ${ }^{160}$. Ponadto wspomniany falsyfikat został spisany tą samą ręką co podrobiony dyplom fundacyjny z 1175 r., musiał zatem powstać w podobnym okresie czasu, tj. pod koniec XIII w. ${ }^{161}$ Wyraźne portyjskie cechy formularza dokumentu, a także pojawienie się $\mathrm{w}$ jego treści dość niecodziennej liczby łanów ziemi przekazanej klasztorowi, zbieżnej z wiadomościami Exordium, może wskazywać, iż sporządzającym pod koniec XIII w. falsyfikaty zakonnikom z Lubiąża znana była zawartość spisanego między 1279 a a1280 r. kopiarza klasztoru macierzystego i mogła posłużyć za inspiracje dla przeprowadzonej przez mnichów modyfikacji wizji najdawniejszych dziejów wspólnoty.

\footnotetext{
159 SUB $1, \mathrm{nr} 331$.

160 Ibidem; UP 1, nr 176.

161 SUB 1, nr 331.
} 


\section{Podsumowanie}

Najwcześniejsza wersja tradycji fundacyjnej klasztoru portyjskiego łączyła powstanie opactwa z postacią biskupa naumburskiego Udona I, który przeniósł konwent z Schmölln do Pforty. Jednak już w pierwszej połowie XIII w. mnisi, najpewniej pod wpływem konfliktu z biskupem Naumburga Engelhardem, dokonali daleko idącej modyfikacji obrazu początków swojej wspólnoty. Po pierwsze, wprowadzili do tradycji zupełnie nieznaną wcześniejszym źródłom postać grafa Brunona z Pleissengau, inicjatora fundacji klasztoru szarych mnichów, a także osobę, która przekazała na założenia opactwa odpowiednie uposażenie. Rola biskupa Udona I została z kolei poważnie przedefiniowana. Z fundatora klasztoru stał się on jedynie realizatorem ostatniej woli grafa i jako jego krewny sprawował opiekę nad cystersami. Tradycja uznająca grafa Brunona za fundatora klasztoru portyjskiego począwszy od początków XIII w. stała się obowiązującą wizją przeszłości opactwa. Kolejne przekazy (Exordium monasterii Portensis, klasztorna inskrypcja) rozbudowywały informacje dotyczacce grafa i jego rodziny. Wraz z postacią Brunona w tradycji portyjskiej pojawił się także wątek przedcysterskich dziejów Schmölln/ Pforty. Począwszy od ogólnikowych informacji o istnieniu w Schmölln bezimiennej wspólnoty klasztornej, poprzez wzmiankę o dwóch fundacjach grafa Brunona, tj. konwentu żeńskiego i klasztoru benedyktyńskiego, a kończąc na powiązaniu dziejów Schmölln z dziećmi grafa Oetwinem i Garburgis. Na fali zainteresowania historią własnej wspólnoty na początku XIII w. do tradycji fundacyjnej Pforty dołączony został także wątek barbarzyńców. Posłużył on mnichom do wyjaśnienia powodów translokacji opactwa z Schmölln do Pforty. Temat ten ewaluował w drugiej połowie XIII w. Nie tylko dookreślono, iż chodziło o Słowian, ale także przywołano bogate w szczegóły opowiadanie o prześladowaniach zakonników przez jednego $\mathrm{z}$ nich. Podsumowując, tradycja fundacyjna klasztoru w Pforcie otrzymała swoją kanoniczną formę w pierwszej połowie XIII w., a następnie była przez kolejne pokolenia zakonników jedynie rozbudowywana o nowe elementy, nie zmieniając już jednak swojej podstawowej warstwy. Pewne inspiracje historią fundacyjną Pforty można odnaleźć także w tradycji jej filii - opactwie w Lubiążu. Należą do nich wątek benedyktyńskich początków wspólnoty, wyeksponowanie udziału biskupa wrocławskiego w fundacji klasztoru czy temat zapóźnionej cywilizacyjnie, pogańskiej ludności zamieszkującej miejsce, gdzie został założony klasztor. 


\section{Streszczenie}

Artykuł przedstawia proces kształtowania się tradycji fundacyjnej klasztoru cystersów w Schmölln/Pforcie począwszy od lat trzydziestych XII a kończąc na schyłku XV w. Analizie została poddana treść tradycji (wątek fundatora, przedcysterskich dziejów, tzw. trudów początków, macierzy, translokacji), środki, za pomocą których zakonnicy tworzyli wizję początków swojej wspólnoty (motywy literackie, symbole, nawiązania biblijne), a także nośniki tradycji (dyplomy, falsyfikaty, fundatio, źródła ikonograficzne). Najwcześniejsze przekazy dotyczące genezy opactwa pojawiły się już w wieku XII. Zawierały przede wszystkim wiadomości na temat translokacji opactwa z Schmölln do Pforty dokonanej przez biskupa Naumburga Udona I. Pierwszym świadectwem aktywnej postawy portyjskich zakonników wobec własnej przeszłości było sporządzenie przez nich na początku wieku XIII kilku falsyfikatów, które miały zabezpieczyć stan posiadania i status prawny klasztornej wspólnoty w sporze z biskupem naumburskim Engelhardem. Wykreowany w nich obraz początków klasztoru, na który składały się postać fundatora grafa Brunona z Pleissengau, dzieje przedcysterskiej wspólnoty w Schmölln czy zagrożenia ze strony miejscowej ludności, zostały z kolei rozbudowane w powstałym w drugiej połowie XIII w. Exordium monasterii Portensis. Tradycja fundacyjna Pforty nie uległa w kolejnych wiekach większym zmianom. W XV w. kontynuowano pamięć o grafie Brunonie jako fundatorze klasztoru i biskupie Udonie I, który odpowiadał za translokację konwentu. Potwierdza to cykl obrazowo-tekstowy, który znajdował się na ścianie południowej klasztoru poświęcony założeniu opactwa, a także zespół rzeźb w klasztornym kościele.

\section{The Ignominious Slavs, an Imaginary Founder, the Benedictines and a Wild Boar. A Foundation Tradition of the Cistercian Monastery at Pforta to the End of the Fifteenth Century}

The article presents the process of the formation of foundation tradition at the Cistercian monastery at Schmölln/Pforta from the 1130s to the late fifteenth century. An in-depth analysis was carried out of the tradition content (the founder, pre-Cistercian history, the so-called teething problems, mother monastery, translocation), means used by the monks to create a vision of the beginnings of their community (literary motifs, symbols, Biblical references), and the tradition carriers (charters, forgeries, fundatio, iconographic sources). The earliest references to the genesis of the abbey date back to the twelfth century. They were made mainly in connection with the translocation of the abbey from Schmölln to Pforta made by Bishop Udon I of Naumburg. The first evidence of the active attitude of the Pforta monks towards their own past was the creation in the early thirteenth century of a number of forged charters that were supposed to secure the possessions and legal status of the monastic community in their dispute with Bishop Engelhard of Naumburg. The image of the monastery origins they created with the figure of their founder Count Bruno of Pleissengau, the history of pre-Cistercian community 
at Schmölln or a threat from local people were in turn expanded in the Exordium monasterii Portensis written in the second half of the thirteenth century. Over the following centuries, the founding Pforta tradition did not change significantly. In the fifteenth century, the memory of Count Bruno as the monastery founded and Bishop Udo I as its translocator was still cherished. This is testified by a pictorial and textual cycle located at the southern wall of the monastery devoted to the erection of the abbey, and a series of sculptures in the monastery church.

Translated by Grażyna Waluga

\section{Bibliografia}

Appelt Heinrich, Urkundenfälschungen in Schlesien, w: Fälschungen im Mittelalter. Internationaler Kongress der Monumenta Germaniae Historica München, 16.-19. September 1986, Hahnsche Buchhandlung, Hannover 1988, MGH. Schriften, t. 33, cz. 4, s. 531-573.

Berne Eric, The Structure and Dynamics of Organizations and Groups, Ballantine Books, New York, 1973.

Bertuch Justin, Chronicon Portense, Verlag Lipsiae: Apelius, Leipzig 1612.

Böhme Paul, Zur Geschichte des Cisterzienser-Klosters St. Marien zur Pforte, w: Einladungs-Programm zu der am 23. Mai 1873 stattfindenden dreihundert und dreissigsten Stiftungsfeier der Königlichen Landesschule Pforta, Heinrich Sieling Verlag, Naumburg 1873, s. 3-38.

Catalogus abbatum Saganensium, wyd. Gustav Adolf Stenzel, w: Scriptores rerum Silesiacarum oder Sammlung schlesischer Geschichtsschreiber, t. 1, Josef Max et Komp. Verlag, Wrocław 1835.

Cetwiński Marek, „Ara demonis”. Od pogańskiego miejsca kultu do cysterskiego klasztoru w Lubiązu, w: Kulturotwórcza rola cystersów na Kociewiu. Pelplin - 725 rocznica powstania opactwa cysterskiego. Materiały z sesji naukowej zorganizowanej w Pelplinie w dniach 21-23 września 2001 r., przez Starostwo Powiatowe w Tczewie, Instytut Historii Uniwersytetu Gdańskiego oraz Zespół do badań nad historia i kultura cystersów w Polsce Uniwersytetu Adama Mickiewicza w Poznaniu, red. Dariusz Dekański, Bernardinum, Pelplin 2002, s. 101-105.

Corssen Wilhelm P., Altertümer und Kunstdenkmale des Cisterzienserklosters St. Marien und der Landesschule zur Pforte, Buchhandlung des Waisenhauses Verlag, Halle 1868.

Cronica domus Sarensis, w: Fontes rerum Bohemicarum, t. 2, wyd. Josef Emler, Museum Království českého, Praha 1874, s. 521-557.

Dorfmüller Petra, Die Zisterzienser und das Kloster Pforte, Schulpforte 2011.

Epperlein Siegfried, „Mit fundacyjny” niemieckich klasztorów cysterskich a relacja mnicha lubiaskiego z XIV wieku, PH 58, 1967, s. 587-604.

Exordium monasterii Portensis, w: Urkundenbuch des Klosters Pforte, t. 1: 1132-1300, wyd. Paul Böhme, Otto Hendel Verlag, Halle 1893, s. 7-9.

Filipek-Misiak Aleksandra, Książę, opat, pochówek. Władza księcia a władza opata w świetle Catalogus Abbatum Saganensium Ludolfa z Żagania, w: Potestas et societas. Władza w średniowiecznej Europie, red. Przemysław Wiszewski, Joanna Wojtkowiak, Wydawnictwo eBooki, Wrocław 2014, s. 13-21. 
Forstner Dorothea, Świat symboliki chrześcijańskiej, Pax, Warszawa 1990.

France James, Cistercian Foundation Narratives in Scandinavia in Their Wider Context, „Cîteaux" 43, 1992, s. 119-160.

Fundationis et Fundatorum Historia, w: Monasticon Anglicanum. A History of the Abbies and Other Monasteries, cz. 5, wyd. William Dugdale, James Bohn publishing house, London 1846, s. 377-384.

Goetz Hans-Werner, Geschichtsschreibung und Geschichtsbewusstsein im hohen Mittelalter, Akademie Verlag, Berlin 1999, Orbis mediaevalis. Vorstellungswelten des Mittelalters, t. 1.

Goetz Hans-Werner, Zum Geschichtsbewußtsein in der alamannisch-schweizerischen Klosterchronistik des hohen Mittelalters (11.-13. Jahrhundert), „Deutsches Archiv” 44, 1988, s. 455-488.

Górka Olgierd, Studya nad dziejami Ślaska. Najstarsza tradycja opactwa Cystersów w Lubiążu, Księgarnia H. Altenberga, Lwów 1911.

Gregorii episcopi Turonensis. Libri historiarum X, wyd. Bruno Krusch, Wilhelm Levison, Hahnsche Buchhandlung, Hannover 1951, MGH SS rer. Merov. 1.

Heath Sidney, The Story of Ford Abbey. From the Earliest Times to the Present Day, Francis Griffiths publishing house, London 1911.

Helmoldus Bozoviensis, Cronica Slavorum, oprac. Bernhard Schmeidler, MGH SrG, t. 32, Hahnsche Buchhandlung, Hannover 1937.

Heutger Nicolaus, Kloster Walkenried. Geschichte und Gegenwart, Lucas Verlag, Berlin 2007, Studien zur Geschichte, Kunst und Kultur der Zisterzienser 27.

Holzfurtner Ludwig, Gründung und Gründungsüberlieferung. Quellenkritische Studien zur Gründungsgeschichte der Bayerischen Klöster der Agilolfingerzeit und ihrer hochmittelalterlichen Überlieferung, Verlag Michael Lassleben, Kallmünz 1984, „Münchner Historische Studien”, Abt. Bayer. Geschichte, t. 11.

Jarecki Helge, Gründungsgeschichten des Zisterzienserklosters St. Marien zur Pforte (Schulpforte) bei Naumburg, „Deutsche Gesellschaft für Archäologie des Mittelalters und der Neuzeit: Mitteilungen der Deutschen Gesellschaft für Archäologie des Mittelalters und der Neuzeit” 27, 2014, s. 207-214.

Jażdżewski Konstanty Klemens, Lubiaż. Losy i kultura umysłowa śląskiego opactwa cystersów (1163-1642), Wydawnictwo UWr, Wrocław 1992.

Jażdżewski Konstanty Klemens, Poglady średniowiecza na fałszowanie dokumentów (w związku z czterema falsyfikatami przywileju fundacyjnego dla cystersów w Lubiażu z 1175 roku), „Sprawozdania Wrocławskiego Towarzystwa Naukowego” 33, 1978, s. 66-71.

Kaczmarek Michał, W sprawie falsyfikatów lubiaskich raz jeszcze, w: Memoria viva. Studia historyczne poświęcone pamięci Izabeli Skierskiej (1967-2014), red. Grażyna Rutkowska, Antoni Gąsiorowski, Instytut Historii PAN, Poznań-Warszawa 2015, s. 190-206.

Kastner Jörg, Historiae fundationum monasteriorum. Frühformen monastischer Institutionsgeschichtsschreibung im Mittelalter, Arbeo Gesellschaft, München 1974, Münchener Beiträge zur Mediävistik und Renaissance-Forschung, t. 18.

Keussen Hermann, Chronikon monasterii Campensis ordinis Cisterciensis, w: Fontes adhuc inediti rerum Rhenanarum. Niederrheinische Chroniken, cz. 2, wyd. Gottfried Eckertz, Heberle Verlag, Köln 1870, s. 329-428. 
Knapp Ulrich, Das Kloster Maulbronn. Geschichte und Baugeschichte, Theiss, Stuttgart 1997.

Könighaus Waldemar, Die Zisterzienserabtei Leubus in Schlesien von ihrer Gründung bis zum Ende des 15. Jahrhunderts, Harrassowitz Verlag, Wiesbaden 2004, Quellen und Studien. Deutsches Historisches Institut Warschau, t. 15.

Kuhn-Rehfus Maren, Das Bistum Konstanz, t. 3: Das Zisterzienserinnenkloster Wald, De Gruyter, Berlin-New York 1992, Germania Sacra, Neue Folge, t. 30.

Kunde Holger, Das Zisterzienserkloster Pforte - eine Fälscherwerkstatt aus dem 13. Jahrhundert Kunde, w: Diplomatische Forschungen in Mitteldeutschland, red. Tom Graber, Leipziger Univ.-Verlag, Leipzig 2005, Schriften zur sächsischen Geschichte und Volkskunde, t. 12, s. 145-161.

Kunde Holger, Das Zisterzienserkloster Pforte. Die Urkundenfälschungen und die frühe Geschichte bis 1236, Böhlau Verlag, Köln-Weimar-Wien 2003, Quellen und Forschungen zur Geschichte Sachsen-Anhalts, t. 4.

Kunde Holger, Vaterabt und Tochterkloster. Die Beziehungen zwischen den Zisterzienserklöstern Pforte und Altzelle bis zum ersten Drittel des 13. Jahrhunderts, w: Altzelle. Zisterzienserabtei in Mitteldeutschland und Hauskloster der Wettiner, red. Martina Schattkowsky, André Thieme, Leipziger Univ.-Verlag, Leipzig 2002, Schriften zur sächsischen Landesgeschichte, t. 3, s. 39-67.

Lange Paul, Chronica Numburgensia, w: Scriptores rerum Germanicarum, praecipue Saxonicarum, t. 2, wyd. Johann B. Mencke, Johann Christian Martini Verlag, Leipzig 1728, s. 1-102.

McGuire Brian P., Conflict and Continuity at Øm Abbey. A Cistercian Experience in Medieval Denmark, Museum Tusculanum, Copenhagen 1976.

Michałowski Roman, Princeps fundator. Studium z dziejów kultury politycznej $w$ Polsce X-XIII wieku, Uniwersytet Warszawski. Instytut Historyczny, Warszawa 1989.

Michałowski Roman, Święta moc fundatora klasztoru (Niemcy XI-XII wieku), KH 91, 1984, 1, s. 3-24.

Modzelewski Karol, Barbarzyńska Europa, Iskry, Warszawa 2004.

Monumenta Lubensia, wyd. Wilhelm Wattenbach, Josef Max et Komp. Verlag, Breslau 1861.

Nahmer Dieter, Die Klostergründung ,in solitudine” - ein unbrauchbarer hagiographischer Topos?, „Hessisches Jahrbuch für Landesgeschichte” 22, 1972, s. 90-111.

Niedermaier Hans, Klostertranslationen bei den Zisterziensern, „Cîteaux” 24, 1973, s. 31-52.

Pahncke Robert, Schulpforte. Geschichte des Zisterzienserklosters Pforte, Koehler \& Amelang Verlag, Leipzig 1956.

Patze Hans, Adel und Stifterchronik. Frühformen territorialer Geschichtsschreibung im hochmittelalterlichen Reich, „Blätter für deutsche Landesgeschichte” 100, 1964, s. 8-81; 101, 1965, s. 67-128.

Patze Hans, Klostergründung und Klosterchronik, „Blätter für deutsche Landesgeschichte" 113, 1977, s. 89-121.

Pauk Marcin, Wspólnota klasztorna jako „środowisko pamięci”. Konwent opactwa Petershausen i podstawy jego tożsamości w pierwszej połowie XII wieku, w: Symboliczne i realne podstawy tożsamości społecznej w średniowieczu, red. Sławomir Gawlas, Paweł Żmudzki, Wydawnictwa UW, Warszawa 2017, s. 138-164. 
Pauk Marcin, Mnisi - fundatorzy - pismo. Cronica Domus Sarensis na tle dziejopisarstwa klasztornego XI-XIV wieku, w: Christianitas Romana. Studia ofiarowane Profesorowi Romanowi Michałowskiemu, red. Krzysztof Skwierczyński, Wydawnictwa UW, Warszawa 2009, s. 234-273.

Regesten des Klosters Werschweiler, wyd. Andreas Naubauer, Verlag des Historischen Vereins der Pfalz, Speyer 1921.

Remensnyder Amy, Remembering Kings Past. Monastic Foundation Legends in Medieval Southern France, Cornell University Press, New York 1995.

Sauer Christine, Fundatio und Memoria. Stifter und Klostergründer im Bild, 1100 bis 1350, Vandenhoeck und Ruprecht Verlag, Göttingen 1993, Veröffentlichungen des Max-Planck-Instituts für Geschichte, t. 109.

Schich Winfried, Klosteranlage und Wasserversorgung bei den Zisterziensern, w: Wirtschaft und Kulturlandschaft. Gesammelte Beiträge 1977 bis 1999 zur Geschichte der Zisterzienser und der „Germania Slavica”, red. Winfried Schich, BWV Berliner Wissenschafts-Verlag, Berlin 2007, s. 173-192.

Schlesinger Walter, Kirchengeschichte Sachsens im Mittelalter, t. 2: Das Zeitalter der deutschen Ostsiedlung (1100-1300), Böhlau-Verlag, Köln-Graz 1962, Mitteldeutsche Forschungen, t. 27.

Schlesisches Urkundenbuch, t. 1: 971-1230, wyd. Heinrich Appelt, Böhlau-Verlag, Wien-Köln-Graz 1971.

Schubert Ernst, Die Arkosolgräber im Sanktuarium der Zisterzienser-Klosterkirche in Schulpforta, w: idem, Dies diem docet. Ausgewählte Aufsätze zur mittelalterlichen Kunst und Geschichte in Mitteldeutschland. Festgabe zum 75. Geburtstag, Böhlau-Verlag, Köln 2003, Quellen und Forschungen zur Geschichte Sachsen-Anhalts, t. 3, s. 443-448.

Späth Marcus, Verflechtung von Erinnerung. Bildproduktion und Geschichtsschreibung im Kloster San Clemente a Casauria während des 12. Jahrhunderts, Berlin Akademie-Verlag, Berlin 2007, Orbis Mediaevalis. Vorstellungswelten des Mittelalters, t. 8.

Szacki Jerzy, Tradycja, Wydawnictwa UW, Warszawa 2011.

Thieme André, Die Burggrafschaft Altenburg. Studien zu Amt und Herrschaft im Übergang vom hohen zum späten Mittelalter, Leipziger Univ.-Verlag, Lipsk 2001, Schriften zur Sächsischen Landesgeschichte, t. 2.

Tomaszek Michał, Klasztor i jego dobroczyńcy. Średniowieczna narracja o opactwie Brauweiler i rodzie królowej Rychezy, Avalon, Kraków 2007.

Trapp Thomas, Die Zisterzienserabtei Weiler-Bettnach (Villers-Bettnach) im Hochund Spätmittelalter, Saarbrücker Druckerei und Verlag, Saarbrücken 1996, Veröffentlichungen der Komission für Saarländische Landesgeschichte und Volksforschung, t. 27.

Tyszkiewicz Lech, Z badań nad narodzinami stereotypów Słowian w historiografii zachodniej wczesnego średniowiecza, w: idem, Barbarzyńcy w Europie. Studia z późnego antyku i wczesnego średniowiecza, Wydawnictwo UWr, Wrocław 2007, s. 31-53.

Urkundenbuch des Hochstifts Naumburg, t. 1: 967-1207, wyd. Felix Rosenfeld, Selbstverlag der Historischen Kommission, Magdeburg 1925.

Urkundenbuch des Klosters Pforte, t. 1: 1132-1300, wyd. Paul Böhme, Otto Hendel Verlag, Halle 1893. 
Wichert Sven, Das Zisterzienserkloster Doberan im Mittelalter, Lukas-Verlag, Bad Doberan 2000, Studien zur Geschichte, Kunst und Kultur der Zisterzienser, t. 9.

Warnatsch Stephan, Geschichte des Klosters Lehnin, 1180-1542, Lukas-Verlag, Berlin 2000, Studien zur Geschichte, Kunst und Kultur der Zisterzienser, t. 12.

Weigel Petra, Slawen und Deutsche. Ethnische Wahrnehmungen und Deutungsmuster in der hoch- und spätmittelalterlichen Germania Slavica, w: Ostsiedlung und Landesausbau in Sachsen. Die Kührener Urkunde von 1154 und ihr historisches Umfeld, red. Enno Bünz, Leipziger Univ.-Verlag, Leipzig 2008, Schriften zur sächsischen Geschichte und Volkskunde, t. 23, s. 47-94.

Wirtembergisches Urkundenbuch, t. 2: 1138-1212, oprac. Eduard Kausler, Köhler Verlag, Stuttgart 1858.

Wiszewski Przemysław, Nowe jak stare, czyli o tradycji z falsyfikatów lubiaskiego dokumentu fundacyjnego (XIII-XIV w.), w: Stare i nowe w średniowieczu. Pomiędzy innowacją a tradycja, red. Sławomir Moździoch, Wydawnictwo Instytutu Archeologii i Etnologii PAN. Oddział, Wrocław 2009, s. 411-427.

Wojciechowska Beata, Ekskomunikowani w świetle średniowiecznego prawa kanonicznego - pozycja społeczna, religijna i prawna, „Studia Historica Gedanensia” 4, 2013, s. 25-38.

Zimand Roman, Problem tradycji, w: Proces historyczny w literaturze i sztuce. Materiały z sesji naukowej (maj 1956), red. Maria Janion, Aniela Piorunowa, PIW, Warszawa 1967, s. 360-379.

Zwanzig Christopher, Gründungsmythen fränkischer Klöster im Früh- und Hochmittelalter, Steiner Verlag, Sttutgart 2010, Geschichte. Beiträge zur Hagiographie, t. 9.

Biogram: Monika Michalska, doktorantka w Instytucie Historii Uniwersytetu Jagiellońskiego. Zainteresowania badawcze: historia zakonu cysterskiego, tradycje fundacyjne klasztorów cysterskich na Śląsku, Księga henrykowska, recepcja dzieł historiograficznych w opactwach cysterskich; kontakt: michalska.monika@ gmail.com. 